\title{
Review Article \\ Vitamin D: Are We Ready to Supplement for Breast Cancer Prevention and Treatment?
}

\author{
Katherine D. Crew ${ }^{1,2,3}$ \\ ${ }^{1}$ Department of Medicine, Division of Hematology/Oncology, College of Physicians and Surgeons, Columbia University, \\ New York, NY 10032, USA \\ ${ }^{2}$ Department of Epidemiology, Mailman School of Public Health, Columbia University, New York, NY 10032, USA \\ ${ }^{3}$ Herbert Irving Comprehensive Cancer Center, Columbia University, New York, NY 10032, USA
}

Correspondence should be addressed to Katherine D. Crew; kd59@columbia.edu

Received 8 January 2013; Accepted 29 January 2013

Academic Editors: C.-X. Pan, S. Patel, A. E. Pinto, and T. Yokoe

Copyright (C) 2013 Katherine D. Crew. This is an open access article distributed under the Creative Commons Attribution License, which permits unrestricted use, distribution, and reproduction in any medium, provided the original work is properly cited.

\begin{abstract}
Vitamin D deficiency is a potentially modifiable risk factor that may be targeted for breast cancer prevention and treatment. Preclinical studies support various antitumor effects of vitamin D in breast cancer. Numerous observational studies have reported an inverse association between vitamin $\mathrm{D}$ status, including circulating 25-hydroxyvitamin $\mathrm{D}(25(\mathrm{OH}) \mathrm{D})$ levels, and breast cancer risk. The relationship between vitamin D and mammographic density, a strong predictor of breast cancer risk, remains unclear. Studies analyzing the link between genetic polymorphisms in vitamin $\mathrm{D}$ pathway genes and breast cancer incidence and prognosis have yielded inconsistent results. Vitamin D deficiency among breast cancer patients has been associated with poorer clinical outcomes and increased mortality. Despite a number of clinical trials of vitamin D supplementation, the efficacy, optimal dosage of vitamin $\mathrm{D}$, and target blood level of $25(\mathrm{OH}) \mathrm{D}$ for breast cancer prevention have yet to be determined. Even with substantial literature on vitamin $\mathrm{D}$ and breast cancer, future studies need to focus on gaining a better understanding of the biologic effects of vitamin $\mathrm{D}$ in breast tissue. Despite compelling data from experimental and observational studies, there is still insufficient data from clinical trials to make recommendations for vitamin D supplementation for breast cancer prevention or treatment.
\end{abstract}

\section{Introduction}

Breast cancer confers significant morbidity and mortality among women in the United States. Due to the magnitude of this disease, considerable research effort has been directed toward identifying breast cancer risk factors to target for prevention. However, relatively few modifiable lifestyle and environmental factors have been associated with reduced breast cancer risk. Chemoprevention refers to altering the carcinogenesis process with a drug intervention. The selective estrogen receptor modulators (SERMs), tamoxifen [1] and raloxifene [2], and aromatase inhibitor (AI), exemestane [3], have been shown to reduce breast cancer incidence. These antiestrogens are the only drugs that have been approved by the USA Food and Drug Administration for breast cancer prevention in high-risk population; however, uptake has been poor in the prevention setting. Due to serious toxicities associated with SERMs, namely, endometrial cancer and thromboembolic disease, and chronic toxicities of AIs, such as hot flashes, arthralgias, and osteoporosis, they have not gained widespread acceptance in the primary prevention setting. In addition, these antiestrogens do not lower the incidence of more aggressive estrogen receptor- (ER-) negative breast cancers, which account for about one-third of all breast tumors and are associated with a poorer prognosis compared with ER-positive breast cancer. Therefore, a priority in breast cancer chemoprevention includes developing safe and tolerable agents for potential chronic use that are effective against ER-negative tumors. There is an urgent need to develop agents which modulate nonendocrine biochemical pathways in breast carcinogenesis.

The earliest observations linking vitamin $\mathrm{D}$ with cancer came from ecological studies [4]. Since ultraviolet B (UVB) light is essential for cutaneous production of vitamin D, sunlight exposure may be a surrogate for vitamin $\mathrm{D}$ levels. One study suggested a potential link between increasing rates of 


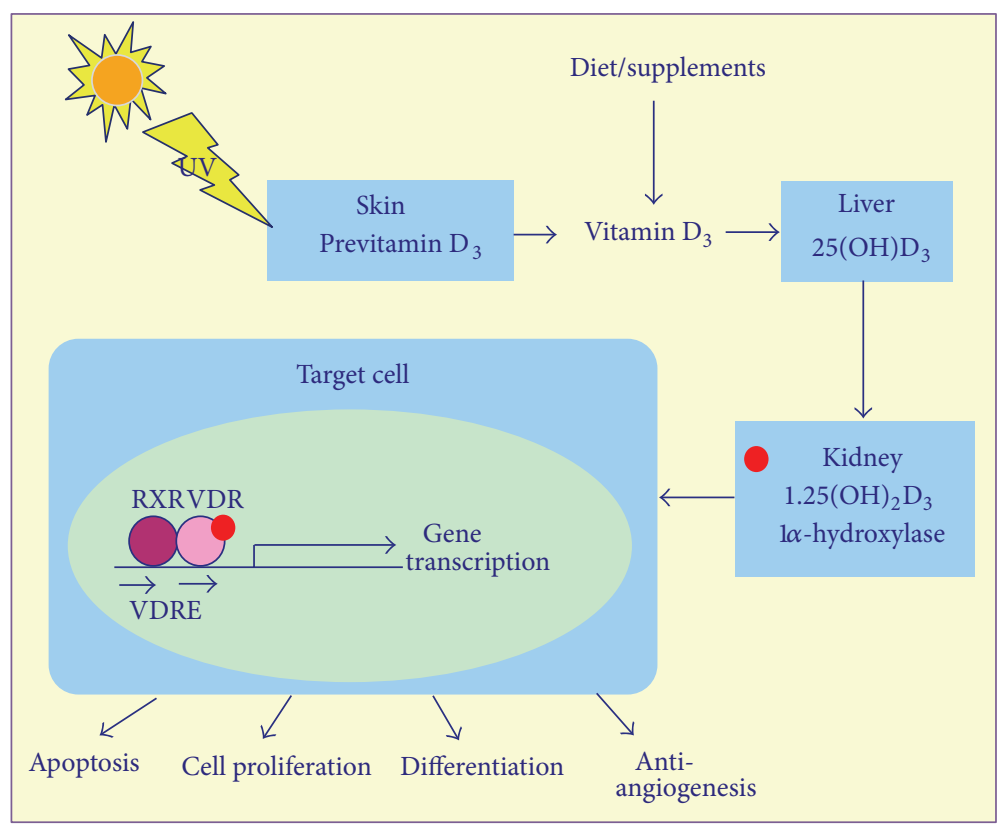

FIGURE 1: Vitamin D metabolism.

certain cancers and geographic latitude, allowing researchers to postulate that decreased sunlight exposure, leading to less endogenous production of vitamin $\mathrm{D}$, may in fact increase rates of malignancy [5]. Other ecological studies have associated increased sunlight exposure with low breast cancer incidence and mortality [6-10]. These studies laid the foundation for examining the hypothesis that vitamin $\mathrm{D}$ deficiency increases cancer risk and mortality, including breast cancer.

As a result of heightened interest in this association, there have been a number of recent observational studies, as well as clinical trials of vitamin D supplementation, examining the relationship between vitamin $\mathrm{D}$ status and breast cancer. Vitamin D deficiency is often defined as a serum 25-hydroxyvitamin $\mathrm{D}(25(\mathrm{OH}) \mathrm{D})$ less than $20 \mathrm{ng} / \mathrm{mL}$ or $50 \mathrm{nmol} / \mathrm{L}$ $(1 \mathrm{ng} / \mathrm{mL}=2.5 \mathrm{nmol} / \mathrm{L})$. This has become a shared concern among physicians, many of whom now routinely screen for vitamin $\mathrm{D}$ deficiency and/or recommend supplementation both in healthy women and breast cancer patients. This interest prompted a 2010 Institute of Medicine (IOM) report addressing vitamin D supplementation [11]. The recommended dietary allowance (RDA) of vitamin D was increased from $400 \mathrm{IU}$ to $600 \mathrm{IU}$ daily for persons 70 years and younger and 800 IU daily for persons over 70 years, intakes corresponding to serum 25(OH)D greater than $20 \mathrm{ng} / \mathrm{mL}$ (or $50 \mathrm{nmol} / \mathrm{L}$ ). In addition, the upper safety limit in healthy individuals was raised from 2000 IU to 4000 IU daily. However, the IOM also raised concerns about negative health effects for circulating 25(OH)D levels above $50 \mathrm{ng} / \mathrm{mL}$ (or $125 \mathrm{nmol} / \mathrm{L}$ ) [11]. After a thorough review of the literature, they concluded that there was insufficient evidence to recommend vitamin $\mathrm{D}$ supplementation for cancer prevention or treatment (http:// www.IOM.edu/vitaminD). In this paper, we evaluate the current knowledge about the anticancer properties of vitamin $\mathrm{D}$ and its association with breast cancer, with an emphasis on the literature published within the past 5 years. We conclude by discussing future directions in this field.

Vitamin D does not meet the strict definition of a vitamin, an essential nutrient that the body cannot synthesize in sufficient quantities. It represents a fat-soluble prohormone that must be modified within the body to produce its active metabolites (Figure 1) [12]. It can exist in two forms: vitamin $\mathrm{D}_{3}$ (cholecalciferol), which is metabolized in the skin by the action of ultraviolet B (UVB) light on a cholesterol product which is synthesized in the skin (7-dehydrocholesterol), or vitamin $\mathrm{D}_{2}$ (ergocalciferol), which is obtained via plant-based dietary sources. Foods of animal origin rich in vitamin $\mathrm{D}_{3}$ include egg yolk, dairy fat, liver, and oily fish [4]. Modest amounts of vitamin D come from food sources, but the majority of vitamin D (up to 90\%) comes from endogenous production in the skin. As a result, wide variability in vitamin $\mathrm{D}$ status occurs due to differences in geographic location, season, sun avoidance behaviors, sunscreen use, increasing age and skin pigmentation (due to decreased skin synthesis of vitamin $\mathrm{D}$ ), obesity (due to fat sequestration of vitamin $\mathrm{D}$ ), and other lifestyle factors [13]. Vitamin D deficiency is surprisingly common, especially among the elderly, blacks, and residents of northern climates [14].

Whether derived from the diet or synthesized in the skin, the precursor form of cholecalciferol/ergocalciferol is then transferred bound to vitamin $\mathrm{D}$ binding protein (DBP) within the bloodstream to the liver, where it is hydroxylated by mitochondrial and microsomal 24-hydroxylase (encoded by CYP24A1) to 25-hydroxyvitamin $\mathrm{D}(25(\mathrm{OH}) \mathrm{D})$ or calcidiol. Although $25(\mathrm{OH}) \mathrm{D}$ has low biological activity, it is the major circulating form and serves as an integrated measure of vitamin D from all sources such as diet, supplements, and sunlight exposure [15]. This product is taken to the kidneys, where it is hydroxylated by mitochondrial $1 \alpha$-hydroxylase 
(encoded by CYP27B1)into 1,25-dihydroxyvitamin D $\left(1,25(\mathrm{OH})_{2} \mathrm{D}\right)$ or calcitriol, the hormonally active form [16]. Many extrarenal tissues also express $1 \alpha$-hydroxylase and, therefore, have the enzymatic machinery to locally activate vitamin $\mathrm{D}$, which acts in a paracrine and autocrine manner in these tissues [17]. Circulating $25(\mathrm{OH}) \mathrm{D}$ is the substrate for conversion to $1,25(\mathrm{OH})_{2} \mathrm{D}$ in target tissues by $1 \alpha$-hydroxylase and may be the limiting factor in local activation of vitamin $\mathrm{D}$ [18]. In addition, cancer cells express $1 \alpha$-hydroxylase; therefore, raising serum $25(\mathrm{OH}) \mathrm{D}$ levels may be a useful chemopreventive and treatment strategy to allow intratumor synthesis of calcitriol [19].

Calcitriol is further hydroxylated by 24-hydroxylase (encoded by CYP24A1), creating two less active forms, $24,25(\mathrm{OH})_{2} \mathrm{D}$ and $1 \alpha, 24,25(\mathrm{OH})_{2} \mathrm{D}$, which are then excreted primarily in the feces [20]. In target tissues, including cancer cells, calcitriol induces expression of 24-hydroxylase [21]. Therefore, coadministration of calcitriol with an agent that inhibits 24-hydroxylase (e.g., the soy isoflavone, genistein) may be a rational combination strategy for cancer prevention and treatment [22]. Using vitamin D analogs which resist 24-hydroxylation is an alternative strategy for cancer therapy [23].

The vitamin D receptor (VDR) is a ligand-dependent transcription factor that is part of a nuclear receptor superfamily. The receptor is comprised of two zinc finger structures with a characteristic DNA-binding domain and a carboxyterminal ligand-binding domain [24]. When bound to its ligand, calcitriol $\left(1,25(\mathrm{OH})_{2} \mathrm{D}\right)$, VDR dimerizes with the retinoid $\mathrm{X}$ receptor ( $\mathrm{RXR})$, causing a conformational change that allows the heterodimer to translocate into the nucleus, where it binds to vitamin D response elements (VDRE) in promoter regions, allowing for transcriptional regulation of target genes, such as $p 21, p 27, c$-fos, and $c-m y c[16,25]$. VDR regulates a wide range of cellular mechanisms central to cancer development, such as apoptosis, cell proliferation, differentiation, angiogenesis, and metastasis [26]. In genomic profiling experiments conducted in breast cancer cell lines cultured with calcitriol (activated vitamin D) and feeding studies of cholecalciferol (parent vitamin D) in mouse models of breast cancer, vitamin $\mathrm{D}$ was shown to impact signaling pathways in differentiation, alter metabolism, remodel of extracellular matrix, and innate immunity [27]. In fact, almost 3\% of the human genome is thought to be either directly or indirectly regulated by vitamin $\mathrm{D}$ [16].

\section{Vitamin D Metabolism}

In an effort to gain a better understanding of the biologic effects of high dose vitamin $\mathrm{D}$ for breast cancer prevention, the Southwest Oncology Group (SWOG) is embarking on a phase IIB randomized double-blind placebo-controlled biomarker modulation study in 200 premenopausal women at high-risk for breast cancer development, based upon breast cancer risk assessment tools, presence of high-risk benign breast lesions, personal history of breast cancer, or hereditary breast cancer syndromes (Figure 2) (clinicaltrials.gov
NCT01097278). Additionally, these women must have a baseline serum $25(\mathrm{OH}) \mathrm{D}$ of less than $32 \mathrm{ng} / \mathrm{mL}$ (or $80 \mathrm{nmol} / \mathrm{L}$ ). They will be randomized to either vitamin $D_{3} 20,000 \mathrm{IU}$ weekly or matching placebo for one year. As this trial will be targeting premenopausal women with insufficient blood levels of $25(\mathrm{OH}) \mathrm{D}$, both groups will be supplemented with a standard dose of vitamin $\mathrm{D}_{3} 600 \mathrm{IU}$ daily. The primary endpoint of this trial is change in the intermediate biomarker, mammographic density. Secondarily, serial blood and benign breast tissue will be collected to assess serum and tissue-based biomarkers, respectively. Using a similar study design, the Cancer and Leukemia Group B (CALGB) is testing the effects of vitamin D 2000 IU daily for 12 months on mammographic density in 250 premenopausal women with increased mammographic density (clinicaltrials.gov NCT01224678). Both of these trials are conducting serial breast tissue sampling before and after the 1-year intervention to evaluate target tissue effects of vitamin D. For example, differential mRNA and protein expression of $1 \alpha$-hydroxylase $(C Y P 27 B 1$, the activating enzyme) and 24-hydroxylase (CYP24A1, the deactivating enzyme) were demonstrated between breast cancer and benign breast tissue [28]. Differential protein expression by immunohistochemistry was noted comparing benign breast lesions to invasive breast tumors for VDR (93.5\% versus $56.2 \%$ ), $1 \alpha$-hydroxylase ( $55.8 \%$ versus $44.6 \%$ ), and 24 hydroxylase (19.0\% versus $53.7 \%$ ) [29]. Therefore, these trials may elucidate potential target tissue effects and mechanisms of action of vitamin D for breast cancer prevention.

\section{Preclinical Studies of Vitamin D}

Apart from its classical actions on bone and mineral metabolism, vitamin D also has diverse biological effects relevant to carcinogenesis. Calcitriol and various vitamin D analogs have been tested in in vitro studies of cancer cell lines. Interestingly, these studies demonstrated that cancer cells undergo certain physiologic changes, which decrease their susceptibility to calcitriol. Malignant cells have decreased intracellular levels of $1 \alpha$-hydroxylase (the activating enzyme encoded by CYP27B1) compared to normal cells, which decreases intracellular calcitriol production. Furthermore, there is increased breakdown of calcitriol in tumor cells, causing resistance to the antitumor effects of vitamin D [30]. The vitamin D receptor (VDR) itself can also become altered and restricted to the nucleus, decreasing its binding to the predominately cytoplasmic calcitriol [31]. Colon, breast, and lung cancer have all demonstrated downregulation of expression of VDR when compared to normal cells and well-differentiated tumors have shown comparably more VDR expression as measured by immunohistochemistry when compared to their poorly differentiated counterparts [30]. Higher tumor VDR expression has also been correlated with better prognosis in cancer patients [32].

Calcitriol may play an important role in normal mammary development. Animal models to analyze the effect of VDR on cell growth and development include transgenic VDR knockout mice [26]. VDR-deficient mice are born with profound disruption in calcium homeostasis, changes in 
SWOG 0812
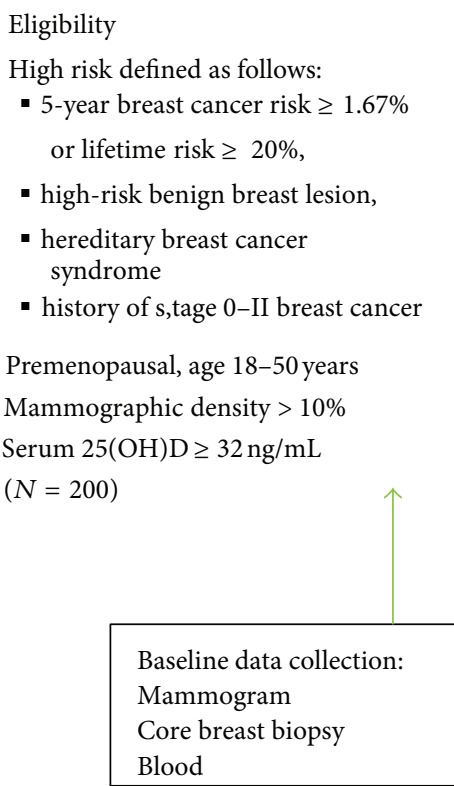

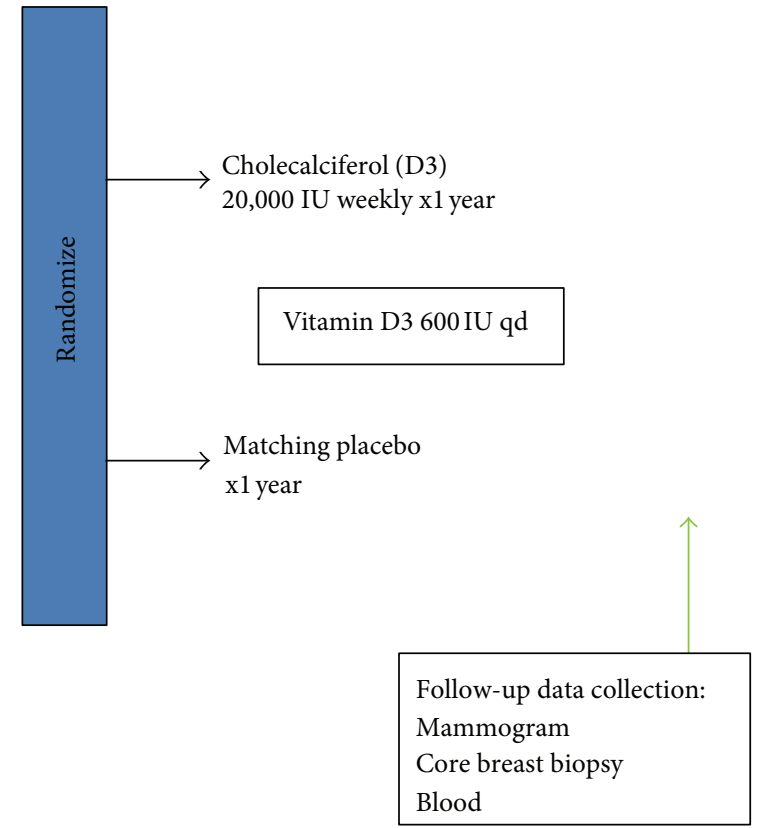

Primary endpoint: change in mammographic density

Secondary endpoints: serum and tissue-based biomarkers, toxicity

FIGURE 2: Schema for Southwest Oncology Group (SWOG) 0812 trial.

duodenal calcium absorption and bone mineralization. Even when supplemental calcium is administered, further phenotypic symptoms present themselves, such as growth retardation, uterine hypoplasia, impaired ovarian folliculogenesis, and reproductive dysfunction [31]. Breast tissue from VDR knockout mice has accelerated growth and branching morphogenesis during pubertal development, as well as increased growth in response to exogenous estrogen and progesterone compared to wild-type mice [26]. VDR knockout mice also demonstrate greater rates of carcinogen-induced preneoplastic mammary lesions compared to wild-type mice [26]. Additionally, $1 \alpha$-hydroxylase expression has been localized to mouse mammary epithelial cells, and treatment with a vitamin D analog increases this expression [33]. In studies of nude mice injected with cultured MCF-7 human breast cancer cells, oral and IV calcitriol inhibited growth of breast tumors [34]. Lee et al. also found that vitamin D analogs significantly suppressed tumor growth in mouse xenograft models [35]. In rodent models of carcinogen-induced breast cancer, calcitriol and its analogs demonstrated significant tumor growth inhibition [36].

VDR has been implicated in cell cycle arrest, apoptosis, and promotion of differentiation. VDR inhibits cell proliferation via $p 21$ and $p 27$, which act on G0/G1 cell cycle arrest. The receptor modulates $p 21$ via direct binding to vitamin D response elements (VDRE) in its promoter region, whereas it induces $p 27$ via activation of various transcription factors and protein stabilization mechanisms [30]. G1 cell cycle arrest is also affected by VDR via direct induction of GADD45-alpha, a regulator of NF- $\kappa \mathrm{B}$ [31]. VDR has also been linked to regulation of apoptosis, as it is transcriptionally upregulated by p53 and has overlapping transcriptional targets. Via the p53 pathway, VDR is able to detect DNA damage and facilitate DNA repair, preventing mutations and promoting appropriate development [31]. VDR can also funcion independently of p53 by upregulating BAX and BAK (proapoptotic proteins) and downregulating BCL2 and BCL-XL (antiapoptotic proteins) [20]. Calcitriol has been shown to induce the differentiation of both normal and malignant cells [31]. Specific pathways affected include both epidermal growth factor receptor (EGFR) and insulin-like growth factor-1 (IGF1), causing inhibition of the MAPK and ERK pathways [37]. By promoting differentiation, VDR facilitates normal development and prevents progression to malignancy.

There is known crosstalk between calcitriol and estrogen receptor (ER) signaling in breast cancer cells. In ER-positive breast cancer cell lines, calcitriol reduced ER expression by direct transcriptional repression of the $E R \alpha$ gene $[38,39]$. Calcitriol also downregulates aromatase gene expression, which encodes the enzyme responsible for estrogen conversion from androgen precursors [40]. Calcitriol inhibits aromatase expression by direct transcriptional repression of human breast cancer cells and cultured preadipocytes [40]. Similarly, in in vivo experiments, calcitriol decreased aromatase expression in human breast cancer cells and the surrounding mammary adipose tissue [40]. Of note, the effects of vitamin D compounds on breast cancer cells also occur via ERindependent pathways $[41,42]$. 
Another potential mechanism of antitumor activity of vitamin $\mathrm{D}$ is the anti-inflammatory effects [43]. Calcitriol regulates the expression of several prostaglandin pathway genes in ER-positive and ER-negative breast cancer cells [40], including decreasing cyclooxygenase-2 (COX-2) and increasing 15-hydroxyprostaglandin dehydrogenase (15-PGDH) levels [44]. Therefore, calcitriol reduced the effects of prostaglandins on proliferation. Given that COX-2 and aromatase expression in breast tumors is tightly coupled [45, 46], calcitriol-mediated reduction in prostaglandins provides an indirect mechanism for downregulation of aromatase expression.

The effects of calcitriol on angiogenesis may be mediated by prostaglandins, which are important proangiogenic factors [43]. Calcitriol and vitamin D analogs also directly inhibited the proliferation of endothelial cells via vascular endothelial growth factor (VEGF), the most potent stimulator of angiogenesis [47, 48]. Calcitriol also inhibited VEGFinduced endothelial cell tube formation in vitro $[47,48]$ and decreased tumor vascularization in mouse xenografts of VEGF-overexpressing cells [49].

To evaluate vitamin D's therapeutic potential, researchers have studied the effects of using calcitriol in combination with other chemotherapeutic agents. Vitamin D can potentiate the effects of certain therapies such as platinum analogs, taxanes, and DNA-intercalating agents. Ma et al. evaluated the combination of vitamin $\mathrm{D}$ and cisplatin in a squamous cell carcinoma (SCC) model and found that pretreatment with calcitriol enhanced the effects of cisplatin on induction of apoptosis [50]. Similarly, Chaudhary et al. determined that pretreatment of breast cancer cells in vitro with a vitamin $\mathrm{D}$ analog enhanced the effects of Adriamycin as well as irradiation by causing apoptosis, reducing clonogenic survival, and decreasing viable cell numbers [51]. Paclitaxel and calcitriol combinations have been studied in SCC and prostate cancer cell lines [52]. Interestingly, many of these antineoplastic agents have been found to inadvertently increase vitamin $D$ levels by decreasing the stability of CYP24A1 mRNA (encoding the deactivating enzyme, 24-hydroxylase), demonstrating a method by which these agents work synergistically with vitamin D [30].

Together these preclinical studies point to specific mechanisms of action of vitamin $\mathrm{D}$ in cancer prevention and treatment.

\section{Vitamin D Status and Breast Cancer Risk}

Some epidemiological data support an inverse association between vitamin D status (including sunlight exposure, dietary and supplement intake, and direct measurement of circulating vitamin D levels) and breast cancer risk, which has resulted in increased interest in the use of vitamin $D$ for breast cancer prevention. In addition to the ecological studies, a significant inverse association was seen between personal ultraviolet B (UVB) exposure and breast cancer risk [53].

Among observational studies examining the association between vitamin $\mathrm{D}$ intake from diet and supplements, 10 were case-control studies [54-63] and 10 cohort studies [64-73].
A recent meta-analysis found a significant inverse association between high versus low vitamin $\mathrm{D}$ intake and breast cancer risk $($ relative risk $(\mathrm{RR})=0.91,95 \%$ confidence interval $(\mathrm{CI})=$ 0.85-0.97) [74]. One case-control study found no association between vitamin $\mathrm{D}$ and calcium intake from food only and breast cancer risk, but supplemental vitamin $\mathrm{D}$ intake of $>400$ IU daily compared to no intake was associated with reduced risk (odds ratio $(\mathrm{OR})=0.76,95 \% \mathrm{CI}=0.59-0.98$ ). However, the National Health and Nutrition Examination Survey (NHANES) follow-up study [64] found no association between dietary and supplemental intake of vitamin $\mathrm{D}$ and breast cancer, consistent with more recent reports [70-72]. In this study population, frequent recreational and occupational sunlight exposure was inversely related to breast cancer risk. A limitation of these studies is that dietary intake of vitamin $\mathrm{D}$ is not a complete measure of vitamin $\mathrm{D}$ status and is subject to measurement error. In the French E3N cohort, only in regions with high UVB exposure was high vitamin D intake associated with decreased breast cancer incidence (hazard ratio $(\mathrm{HR})=0.68,95 \% \mathrm{CI}=0.54-0.85)$ [73].

The majority of studies have assessed the effects of dietary and supplemental intake of vitamin D; however, endogenous production is an important source of vitamin D. Circulating 25-hydroxyvitamin D (25(OH)D) concentration correlates with exogenous vitamin $\mathrm{D}$ sources (dietary and supplement intake) and endogenous production through sunlight exposure and is considered the best indicator of vitamin D status $[13,75]$. Circulating levels of $25(\mathrm{OH}) \mathrm{D}$ (calcidiol) and $1,25(\mathrm{OH})_{2} \mathrm{D}$ (calcitriol) may be measured to determine vitamin $\mathrm{D}$ status. The metabolically active form of vitamin $\mathrm{D}, 1,25(\mathrm{OH})_{2} \mathrm{D}$, has low serum levels, a short halflife of 4-6 hours, and is tightly regulated by the kidneys to maintain calcium homeostasis. Furthermore, serum $1,25(\mathrm{OH}) \mathrm{D}_{2} \mathrm{D}$ may not reflect the autocrine and paracrine effects of vitamin $\mathrm{D}$ in target tissues [76]. 25(OH)D is the metabolite most often quantified due to its long halflife of 3 weeks, which allows it to exist within the serum in concentrations which are three orders of magnitude higher than the serum concentrations of $1,25(\mathrm{OH})_{2} \mathrm{D}[12]$.

$25(\mathrm{OH}) \mathrm{D}$ was first measured using a binding protein assay, in which vitamin $\mathrm{D}$ binding protein (DBP) was used to measure blood levels of $25(\mathrm{OH}) \mathrm{D}$. The problem with this method was that the DBP was relatively nonspecific as it bound to other vitamin D metabolites, causing overestimation of the levels of vitamin D by $10 \%-20 \%$. In 1985 , a radioimmunoassay (RIA) was developed to measure $25(\mathrm{OH}) \mathrm{D}$; however, it too measured other metabolites and had a similar level of inaccuracy. In the last few years, a more specific RIA has been developed to measure $25(\mathrm{OH}) \mathrm{D}$ with $100 \%$ specificity. Other methods used to measure $25(\mathrm{OH}) \mathrm{D}$ include high performance liquid chromatography (HPLC) and mass spectroscopy, which can distinguish between precursor forms of vitamin $\mathrm{D}_{2}$ (ergocalciferol, from plant-based sources) and vitamin $\mathrm{D}_{3}$ (cholecalciferol, from animal sources and endogenous production) [76].

In a recent meta-analysis of observational studies, an increase in serum 25(OH)D by $20 \mathrm{ng} / \mathrm{mL}$ ( or $50 \mathrm{nmol} / \mathrm{L}$ ) was inversely associated with breast cancer risk, with a summary $\mathrm{RR}=0.59(95 \% \mathrm{CI}=0.48-0.73)$ for case-control studies, 
$\mathrm{RR}=0.92(95 \% \mathrm{CI}=0.82-1.04)$ for cohort studies, and $\mathrm{RR}=$ 0.73 (95\% CI $=0.60-0.88)$ for both study designs combined [77]. Another meta-analysis reported that each $10 \mathrm{ng} / \mathrm{mL}$ increase in serum $25(\mathrm{OH}) \mathrm{D}$ was associated with decreased breast cancer risk (summary $\mathrm{RR}=0.89,95 \% \mathrm{CI}=0.81-$ 0.98) [78]. No significant association was seen for circulating $1,25(\mathrm{OH})_{2} \mathrm{D}$ levels and breast cancer risk $(\mathrm{OR}=0.99,95 \% \mathrm{CI}$ $=0.68-1.44)$ [74].

Recent population-based case-control studies have examined levels of serum and/or plasma $25(\mathrm{OH}) \mathrm{D}$ in relation to in situ and invasive breast cancer and found a significant dosedependent inverse association (Table 1). For each $4-5 \mathrm{ng} / \mathrm{mL}$ (or $10-12.5 \mathrm{nmol} / \mathrm{L}$ ) increase in $25(\mathrm{OH}) \mathrm{D}$ level, there was about a $7 \%-12 \%$ reduction in the risk of breast cancer $[79$, $83,89]$. Variations in results between the studies may be due to differences in geographic locations of the study populations, leading to differential blood levels of 25(OH)D. In the German studies, breast cancer cases had a mean serum $25(\mathrm{OH}) \mathrm{D}$ concentration of approximately $18 \mathrm{ng} / \mathrm{mL}$ (or $45 \mathrm{nmol} / \mathrm{L}$ ) [79, 83], whereas in the US study (located at a lower latitude), cases had a higher mean blood level of $25(\mathrm{OH}) \mathrm{D}$ of $27.1 \mathrm{ng} / \mathrm{mL}$ (or $67.8 \mathrm{nmol} / \mathrm{L}$ ) [89]. In case-control studies, measurement of serum $25(\mathrm{OH}) \mathrm{D}$ occurs in individuals already diagnosed with cancer. Therefore, these results need to be interpreted with caution, because behavioral changes after a cancer diagnosis may also influence vitamin D status (e.g., dietary changes, decreased sunlight exposure due to disability or lifestyle changes).

Data from prospective cohort studies have yielded inconsistent results. Two nested case-control studies both found strong inverse associations between vitamin $\mathrm{D}$ status and breast cancer risk $(\mathrm{RR}=0.52,95 \% \mathrm{CI}=0.32-0.85$ and $\mathrm{RR} 0.73$, 95\% CI $=0.55-0.96$, resp.) $[86,88]$. The first study in a Danish population found that the inverse association was more pronounced in premenopausal compared to postmenopausal women $(\mathrm{RR}=0.38,95 \% \mathrm{CI}=0.15-0.97$ versus $\mathrm{RR}=$ $0.71,95 \%$ CI $=0.38-1.30$, resp.) [86]. Three US studies found no association between prediagnostic $25(\mathrm{OH}) \mathrm{D}$ blood levels and breast cancer risk $[82,85,90]$. In the Cancer Prevention study II (CPS-II) Nutrition Cohort, blood draws in postmenopausal women occurred on average 3.9 years prior to breast cancer diagnosis [85]. The second study was a nested case-control study of women participating in the Prostate, Lung, Colorectal, and Ovarian Cancer Screening Trial (PLCO), with a similar average time between baseline blood collection and diagnosis [82]. Higher prediagnostic blood levels of $25(\mathrm{OH}) \mathrm{D}$ were not associated with lower risk of postmenopausal breast cancer in either of these studies; however, each relied on a single baseline measurement. In the Women's Health Initiative (WHI) cohort, a significant association was seen between lower serum 25(OH)D and higher breast cancer incidence; however, the finding was attenuated after adjustment for body mass index (BMI) and physical activity [90]. In another cohort study from Sweden, a weak nonsignificant inverse association between serum 25(OH)D concentration and breast cancer risk was initially observed, which disappeared after adjustment for known breast cancer risk factors [87].
One possible limitation of these prospective cohort studies is the lag time between serum $25(\mathrm{OH}) \mathrm{D}$ measurement in archived blood samples and breast cancer diagnosis. As the follow-up period increases from the time of prediagnostic serum $25(\mathrm{OH}) \mathrm{D}$ level to cancer diagnosis, the risk estimates tend toward the null [91]. One study found an inverse correlation with serum $25(\mathrm{OH}) \mathrm{D}$ and breast cancer risk for followup times up to 10 years, but no correlation beyond 10 years [69]. Circulating 25(OH)D is a useful biomarker for measuring an individual's recent exposure to environmental sources of vitamin $\mathrm{D}$ (i.e., over the past 3 months) but may not reflect lifetime patterns of sunlight exposure and vitamin $\mathrm{D}$ intake. However, more recent data suggests that serum $25(\mathrm{OH}) \mathrm{D}$ levels may remain relatively stable over time [92, 93]. In addition, vitamin $\mathrm{D}$ may be more effective at combating cancer near the time of diagnosis $[94,95]$. To date, there have been no prospective studies evaluating the effect of change in vitamin D level with serial measurements over time on breast cancer risk.

Prior studies have suggested that the association between vitamin $\mathrm{D}$ and breast cancer risk may be stronger for premenopausal women than for postmenopausal women. Two cohort studies showed no reduction in breast cancer risk in association with vitamin D status in postmenopausal women $[65,67]$. The Nurses' Health study found an inverse association between vitamin $\mathrm{D}$ intake and breast cancer risk among premenopausal women, but no association among postmenopausal women [65]. Similarly, the CPS-II Nutrition Cohort observed no association of breast cancer with total vitamin D intake among postmenopausal women [67]. Results from a large population-based case-control study from Ontario suggested that vitamin D status during adolescence when breast development occurs may be most relevant for breast cancer risk [60].

Some studies have demonstrated that the protective effect of vitamin $\mathrm{D}$ on breast cancer risk was independent of tumor hormone receptor status $[79,89]$. Recent data from the Nurses' Health study suggested an inverse association for hormone receptor-negative, but not hormone receptor-positive tumors [96]. The Iowa Women's Health study found a stronger protective effect of vitamin D supplement use among women with breast cancers that were negative rather than positive for estrogen receptor (ER) or progesterone receptor (PR) status [69]. These findings are intriguing, given that we currently do not have any effective chemopreventive agents for ER-negative breast cancer.

More consistent observational data support an inverse association between serum vitamin D levels and colorectal cancer risk [11, 97, 98]. However, all of these observational studies may be subject to confounding since factors associated with vitamin $\mathrm{D}$ deficiency are also linked to higher breast cancer risk, for example, increasing age, obesity (vitamin $\mathrm{D}$ may become sequestered in adipose tissue), low physical activity (correlated with less outdoor activities and sunlight exposure), and other lifestyle factors. Despite promising observational data, individual dietary components (e.g., beta carotene, vitamin E, folic acid, and selenium) have not been successful in preventing cancer in randomized controlled trials [99-103]. Therefore, we must await the results of rigorously 


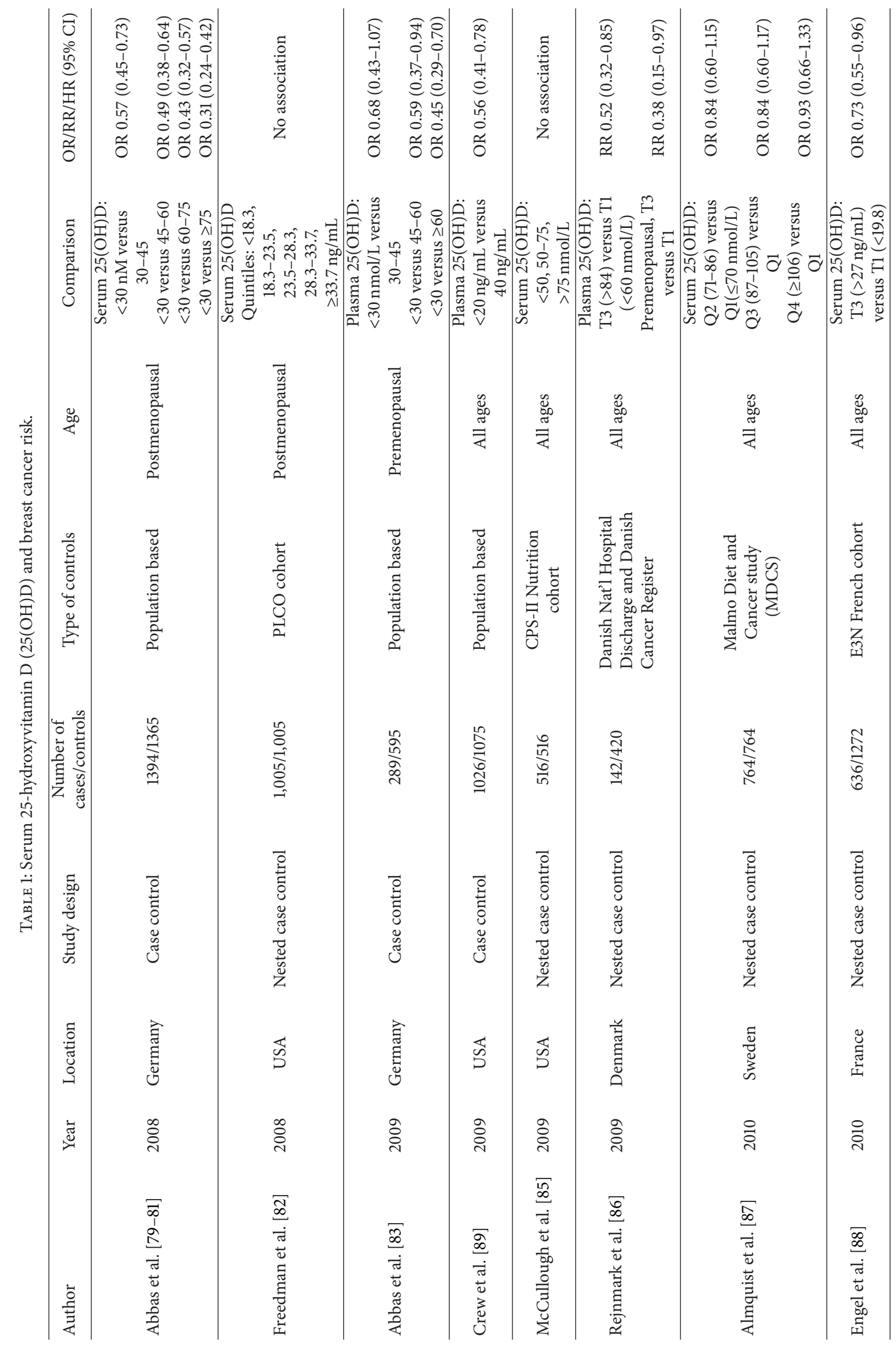


conducted randomized controlled trials before making broad recommendations for vitamin $\mathrm{D}$ supplementation for breast cancer prevention.

\section{Vitamin D and Mammographic Density}

Mammographic density refers to the relative proportions of radiolucent fat and radiodense epithelial and stromal tissue within the breast, as seen on mammography, and is one of the strongest predictors of breast cancer development [104, 105]. As such, mammographic density may serve as a useful intermediate biomarker for breast cancer risk assessment in investigations of potential preventive strategies for this disease. Women in the highest quartile of mammographic density demonstrate a 4-to-6-fold increase in breast cancer incidence as compared to women of similar age in the lowest quartile, for up to 10 years following measurement [104-107]. In addition to qualitative measurements, mammographic density can now be assessed on a continuous scale using computer-assisted techniques, including dense area $\left(\mathrm{cm}^{2}\right)$ and percent density (dense area divided by total breast area) [108] . Percent density partly accounts for differences in breast size; however, it may underestimate mammographic density in obese women with large amounts of fat. Body mass index (BMI) has less of an impact on dense area; therefore, this may be a more useful measure of mammographic density in overweight and obese women. Effective breast cancer chemopreventive agents, such as tamoxifen, have been shown to significantly reduce mammographic density within 12-18 months of initiation [109]. However, the effects of nonhormonal agents on mammographic density remain uncertain. The validation of modifiable intermediate biomarkers for short-term breast cancer risk assessment is the key to conducting more efficient breast cancer chemoprevention trials.

A recent systematic review, which included fourteen studies, examined the association between vitamin $\mathrm{D}$ and mammographic density [110]. Twelve of the studies were crosssectional [111-122] and two were prospective studies [123, 124]. Vitamin D status was assessed by dietary and supplement intake in nine studies [116-124] and by circulating 25 -hydroxyvitamin D $(25(\mathrm{OH}) \mathrm{D})$ levels in five studies [111115]. Furthermore, only four studies considered dense area in addition to percent density as a measure of mammographic density $[111,114,115,119]$, and five studies included populations which were diverse by race and ethnicity $[114,115,119-$ 121].

In the nine studies which assessed dietary intake of vitamin D, five studies reported a significant inverse association between vitamin $\mathrm{D}$ and mammographic density [112, 117$119,122]$. When stratified by menopausal status, much of the association was limited to premenopausal women [117119]. The association between vitamin $D$ intake and mammographic density among premenopausal women was the strongest in women with high insulin-like growth factor-I (IGF-I) and low IGF binding protein-3 (IGFBP-3) levels [118], suggesting that vitamin $\mathrm{D}$ may modulate mammographic density and breast cancer risk via IGF signaling. In a substudy of the Women's Health Initiative (WHI), no association was observed between vitamin D or calcium intake and mammographic density among postmenopausal women, but supplemental vitamin $\mathrm{D}$ use was associated with lower density in younger women [121]. Two additional studies found no correlation between vitamin $\mathrm{D}$ and mammographic density among postmenopausal women $[125,126]$.

More recent studies that assessed serum $25(\mathrm{OH}) \mathrm{D}$ in relation to mammographic density have reported null findings [111-115]. One study found no significant relationship between 25(OH)D blood levels and mammographic density, although women in the highest quartile of serum $25(\mathrm{OH}) \mathrm{D}$ had the lowest breast density [111]. In a case-control study nested within the Nurses' Health study, no association was found between circulating levels of $25(\mathrm{OH}) \mathrm{D}$ and mammographic density in postmenopausal women. However, women in the highest tertile of mammographic density and lowest tertile of plasma $25(\mathrm{OH}) \mathrm{D}$ had a 4 -fold greater risk of breast cancer than women with the lowest mammographic density and highest plasma 25(OH)D [113]. Data from a multiethnic cohort of premenopausal women [114] and breast cancer survivors [115] did not support an association between circulating vitamin $\mathrm{D}$ levels and mammographic density.

A limitation of all of these studies was that the blood collections for serum $25(\mathrm{OH}) \mathrm{D}$ and mammograms were not conducted at the same time point (with time intervals varying from 1 to 8 years). Although most studies adjusted for time between blood draws and mammograms, this may not account for the seasonal variation in vitamin $\mathrm{D}$ status. Brisson et al. reported synchronized seasonal variations of mammographic density and 25(OH)D blood levels, demonstrating that the lowest breast density was observed in early December, approximately 4 months after peak serum 25(OH)D [112] .

Another potential confounder is obesity, which has been positively associated with postmenopausal breast cancer risk [127] and is also inversely related to vitamin D status and mammographic density. The higher prevalence of vitamin D deficiency among overweight and obese individuals may be due to decreased bioavailability of fat-soluble vitamin $\mathrm{D}$ and sequestration in adipose tissue [128]. One study estimated that low vitamin D status may contribute up to $40 \%$ of the breast cancer risk attributable to high BMI [129]. However, a recent nested case-control study of the National Surgical Adjuvant Breast and Bowel Project-(NSABP-) P1 trial, which randomized high-risk women to 5 years of tamoxifen versus placebo, found that serum $25(\mathrm{OH}) \mathrm{D}$ was not an independent predictor of breast cancer risk after adjustment for BMI [130].

No longitudinal studies to date have documented changes in vitamin $\mathrm{D}$ status over time in relation to changes in breast density. The WHI trial, which randomized postmenopausal women to calcium plus vitamin D 400 IU daily or placebo, reported no significant difference in mammographic density after a year of supplementation [131]. However, the ratio of mean density comparing calcium and vitamin $\mathrm{D}$ supplementation to placebo was 0.67 ( $95 \% \mathrm{CI}=0.41-1.07$ ) with $\geq 80 \%$ study drug compliance and no hormone replacement therapy use. These inconsistent results suggest that potential cancer preventive effects of vitamin $\mathrm{D}$ may not be mediated by mammographic density. 


\section{Vitamin D Pathway Genetic Polymorphisms and Breast Cancer Risk}

Interindividual variability in response to vitamin D supplementation may be partially due to single nucleotide polymorphisms (SNPs) in vitamin-D-related genes. Polymorphisms are subtle DNA sequence variations, which occur commonly in a given population $(>1 \%)$ and may have functional significance with modest biological effects. A complementary approach to testing the vitamin-D-cancer hypothesis is to study polymorphisms in the vitamin $\mathrm{D}$ receptor (VDR), a key mediator of vitamin D activity which is expressed in normal and malignant breast cells [132].

The VDR gene is comprised of $>100 \mathrm{~kb}$ with six promoter regions, six alternatively spliced untranslated exons, and eight protein-coding exons [133]. Over 470 SNPs have been reported in the human VDR gene, but the restriction fragment length polymorphisms of Fokl (rs10735810) on exon 2, Apal (rs7975232) and Bsml (rs1544410) on intron 8, and Taql (rs731236) on exon 9 have been the most frequently studied [134]. Population studies indicate that genetic variations in the VDR gene may affect breast cancer risk, particularly in premenopausal women $[135,136]$.

The FokI polymorphism is near the $5^{\prime}$-untranslated region (UTR) within the DNA-binding domain and alters the start codon [137]. The variant T allele (also known as $f$ allele) results in a protein that is three amino acids longer and less transcriptionally active in in vitro studies [138]. For example, a large nested case-control study found a positive association between the ff genotype of FokI and breast cancer risk [136], whereas eight other studies found no association with this genotype [80, 139-145]. A recent meta-analysis comparing FokI ff with $F F$ carriers found a significant increase in breast cancer risk (summary OR $=1.30,95 \% \mathrm{CI}=1.04-1.61$ ) [146]. However, Abbas et al. found no association between FokI genotype and breast cancer risk, regardless of serum 25(OH)D concentration or other VDR polymorphisms [80]. Another study found that FokI genotype influenced breast cancer risk when accounting for other VDR polymorphisms in haplotype combinations [139]. Other upstream elements in the VDR promoter, in linkage disequilibrium with the FokI polymorphism, may also be important in determining expression and strength of transactivation.

ApaI, BsmI, and TaqI are located near the $3^{\prime}$-UTR of the $V D R$ gene and are in strong linkage disequilibrium [147]. Because these polymorphisms do not alter the amino acid sequence of the VDR protein, their functional significance is not well understood. These $3^{\prime}$ region sequence variants may interact differently with other upstream sequences in the $V D R$ gene to regulate transcription, translation, or RNA processing $[148,149]$.

Several studies have reported an association between $B s m I ~ b b$ genotype and increased breast cancer risk [139, 140, $145,150,151]$. For example, Trabert et al. reported a 1.5-fold increased breast cancer risk for postmenopausal Caucasian women with the $b b$ genotype; however, this association was not observed among African American women [150]. In addition, women who were homozygous variant for the BsmI polymorphism $(b b)$ had a 4 -fold higher risk of developing metastases compared to women with the $B B$ genotype [151]. In a recent meta-analysis, $B s m I B b$ and $B B$ carriers had a significantly reduced cancer risk at any site among Caucasian populations [146]. Of note, $70 \%$ of commonly used breast cancer cell lines had the high-risk BsmI bb genotype [152].

The TT genotype of the TaqI polymorphism has been associated with reduced circulating levels of vitamin D [153155]. Of ten epidemiologic studies that have assessed the association between the TaqI genotype and breast cancer risk, nine observed no association and one observed a positive association with the $T$ allele [142-144, 151, 156-161]. However, TT genotype in women with high calcium intake was associated with lower breast cancer risk compared to women with the $t t$ or $T t$ genotype and low calcium intake [144]. Therefore, dietary factors may influence the association of VDR genotypes with breast cancer risk.

In terms of the ApaI polymorphism in the VDR gene, the $A a$ and $a a$ genotypes were associated with about a 1.5fold increased breast cancer risk [142]. However, other studies have reported conflicting results with the $A A$ genotype correlating with an elevated risk of breast cancer $[156,159]$. A nested case-control study within the Cancer Prevention study II (CPS-II) Nutrition Cohort examined the association between breast cancer and these four VDR SNPs (FokI, BsmI, ApaI, and TaqI), as well as SNPs in the 24-hydroxylase gene (CYP24A1) and vitamin D-binding protein gene (DBP) [144]. Although breast cancer incidence was not associated with any genotype evaluated, BsmI and TaqI polymorphisms were associated with lower risk among women with high calcium intake. Another study found a significant inverse association between a $D B P$ (also known as group-specific component $(G C)$ gene) polymorphism and breast cancer risk, independent of 25(OH)D blood levels [81]. In addition, no significant associations were observed between vitamin D pathway polymorphisms (VDR, CYP27B1, and $D B P$ genes) and mammographic density, an intermediate biomarker of breast cancer risk [162].

Few studies have explored the joint association of genetic variation in $V D R$ with biomarkers of vitamin $\mathrm{D}$ status, such as serum 25(OH)D. A case-control study nested in the Physicians' Health study found a significant interaction between circulating 25(OH)D levels, VDR FokI genotype, and prostate cancer risk [163]. Among women with vitamin D deficiency (plasma $25(\mathrm{OH}) \mathrm{D}<20 \mathrm{ng} / \mathrm{mL}$ or $<50 \mathrm{nmol} / \mathrm{L}$ ), the FokI ff genotype correlated with reduced risk of breast cancer $(\mathrm{OR}=$ $0.49,95 \%$ CI $=0.29-0.81$ ) [164]. This association is counterintuitive as one would expect that the less-active VDR $f$ allele $[138,165,166]$ would be associated with increased risk. Further research is needed to replicate the differential associations for breast cancer and to clarify the biological mechanisms responsible.

The role of VDR genotype on breast cancer occurrence remains uncertain, but $V D R$ polymorphisms may account for interindividual differences in response to vitamin D. Discrepancies in these results among different study populations may be due to ethnic variation in the frequency of $V D R$ gene polymorphisms $[167,168]$. Potential gene-environment interactions may exist between polymorphisms in the VDR pathway and factors such as vitamin D and calcium intake, 
blood levels of 25(OH)D, and sunlight exposure. Associations between $V D R$ polymorphisms and risk of breast cancer are complex and warrant further research.

\section{Vitamin D and Breast Cancer Survival}

In terms of cancer recurrence and mortality, some studies have demonstrated an inverse relationship between vitamin D status and cancer prognosis. One large study conducted in Norway using tumor registry data from 1964 to 1992 determined that the lowest risk of cancer death occurred in those diagnosed during the seasons associated with the highest levels of vitamin D, summer or fall [169]. The authors postulated that high levels of vitamin $\mathrm{D}$ at the time of diagnosis and during treatment resulted in improved survival for breast, colon, and prostate cancer.

There is a high prevalence of vitamin D deficiency among breast cancer survivors. In a multiethnic cohort of premenopausal breast cancer patients, the prevalence of vitamin D deficiency (defined as $<20 \mathrm{ng} / \mathrm{mL}$ or $50 \mathrm{nmol} / \mathrm{L}$ ) was $74 \%$ [84]. With supplementation of $400 \mathrm{IU}$ of vitamin $\mathrm{D}_{3}$ daily, $<15 \%$ of patients achieved sufficient blood levels of 25hydroxyvitamin $\mathrm{D}(25(\mathrm{OH}) \mathrm{D})$ (defined as $>30 \mathrm{ng} / \mathrm{mL}$ or $>75 \mathrm{nmol} / \mathrm{L}$ ). Among 500 newly diagnosed breast cancer patients, $69 \%$ were found to have insufficient serum $25(\mathrm{OH}) \mathrm{D}$ concentration (defined as $<32 \mathrm{ng} / \mathrm{mL}$ or $<80 \mathrm{nmol} / \mathrm{L}$ ) [170]. Furthermore, they found that circulating 25(OH)D levels varied by stage of disease with regional invasive disease having significantly lower vitamin $\mathrm{D}$ than in situ disease. After cancer patients were supplemented with vitamin $\mathrm{D}_{3} 8000 \mathrm{IU}$ daily, mean serum 25(OH)D increased from $19.7 \mathrm{ng} / \mathrm{mL}$ $(49.3 \mathrm{nmol} / \mathrm{L})$ to $37.6 \mathrm{ng} / \mathrm{mL}(94 \mathrm{nmol} / \mathrm{L})$; however, many remained in the insufficient range [171]. Another study found a $66.5 \%$ prevalence of vitamin $\mathrm{D}$ deficiency/insufficiency (defined as $<32 \mathrm{ng} / \mathrm{mL}$ or $<80 \mathrm{nmol} / \mathrm{L}$ ) among 224 women with early-stage breast cancer, which was more common among non-Whites and women with later stage disease [172]. These breast cancer patients received either no vitamin D supplementation, low-dose vitamin D (1000 IU daily), or highdose vitamin D (50,000 IU weekly) based upon their baseline serum 25(OH)D. Of note, only high-dose supplementation significantly increased 25(OH)D blood levels [172].

More recent studies have examined the association between circulating $25(\mathrm{OH}) \mathrm{D}$ levels with breast cancer recurrence and survival [82, 173-175]. Goodwin et al. used a cohort of incident breast cancer cases from Canada, 75 years of age or younger [173]. Vitamin D levels were mostly insufficient or deficient, defined as $20-29 \mathrm{ng} / \mathrm{mL}(50-72 \mathrm{nmol} / \mathrm{L})$ and $<20 \mathrm{ng} / \mathrm{mL}(<50 \mathrm{nmol} / \mathrm{L})$, respectively. Only $24 \%$ of women in this cohort were categorized as sufficient $(\geq 30 \mathrm{ng} / \mathrm{mL}$ or $\geq 75 \mathrm{nmol} / \mathrm{L}$ ) [173]. In univariate analysis, both distant disease-free survival (DDFS) and overall survival (OS) were significantly worse in women with vitamin D deficiency compared to a reference group with sufficient levels $(\mathrm{HR}=1.94$, $95 \% \mathrm{CI}=1.16-3.25$ and $\mathrm{HR}=1.73,95 \% \mathrm{CI}=1.05-2.86$, resp.). However, in multivariate analysis the risk was attenuated; low vitamin D levels were only associated with DDFS (HR = $1.71,95 \% \mathrm{CI}=1.02-2.86)$. Of note, the prognostic effects of vitamin $\mathrm{D}$ did not differ by tumor hormone receptor status. Another study in 607 postmenopausal women with early stage hormone receptor-positive breast cancer participating in a clinical trial of tamoxifen with or without octreotide found no association between baseline serum 25(OH)D and relapse-free survival [174]. In a nested case-control study within the Women's Healthy Eating and Living (WHEL) cohort, no association between serum 25(OH)D at diagnosis and breast cancer recurrence was observed; however, vitamin $\mathrm{D}$ intake among premenopausal women was inversely associated with recurrence [175].

Prospective studies evaluating the prognostic role of baseline circulating $25(\mathrm{OH}) \mathrm{D}$ levels for cancers of other disease sites have yielded mixed results. In a cohort study of patients with stage I-II non-small-cell lung cancer (NSCLC), serum $25(\mathrm{OH}) \mathrm{D}$ concentration at diagnosis did not correlate with clinical outcomes, except in a subset of patients with IBIIB disease [95]. However, in patients with advanced NSCLC, no difference in survival by circulating $25(\mathrm{OH}) \mathrm{D}$ levels was observed [176]. In two studies of colon cancer patients, a significant inverse association was reported between serum $25(\mathrm{OH}) \mathrm{D}$ and overall mortality $[177,178]$. Studies in prostate cancer and melanoma patients demonstrated that high serum $25(\mathrm{OH}) \mathrm{D}$ was significantly related to improved prognosis and a decreased risk of relapse and death $[179,180]$.

A limitation of all of these studies was that $25(\mathrm{OH}) \mathrm{D}$ blood levels were assessed at a single time point and no studies to date have evaluated change in serum 25(OH)D over time in relation to cancer prognosis. In addition, not all of these studies adjusted for age, race, body mass index, level of physical activity, and season, which can influence $25(\mathrm{OH}) \mathrm{D}$ blood levels as well as clinical outcomes [181]. Since association studies do not prove causality, low serum 25(OH)D may just be a marker of poor health among cancer patients.

Significant racial disparities in breast cancer clinical outcomes exist between African American and White women. Potential explanations for this health disparity include socioeconomic status, lifestyle factors, and access to health care; however, race is still an independent prognostic factor for breast cancer. Due to greater skin pigmentation, the mean serum 25(OH)D among African Americans is significantly lower compared to the white $(16 \mathrm{ng} / \mathrm{mL}$ (or $40 \mathrm{nmol} / \mathrm{L}$ ) versus $26 \mathrm{ng} / \mathrm{mL}$ (or $65 \mathrm{nmol} / \mathrm{L}$ ), resp.) [14]. Vitamin D deficiency may account for some of the racial disparities between Blacks and Whites for breast cancer, colorectal cancer, cardiovascular disease, and all-cause mortality [182]. Given the high prevalence of vitamin D deficiency among African Americans, this may represent a potentially modifiable risk factor to target to reduce these health disparities.

A number of studies have assessed VDR expression in tumor samples and VDR polymorphisms as prognostic markers. In studies involving patients with colorectal cancer, cholangiocarcinoma, and renal cancer, VDR tumor expression was associated with longer survival [183-185]. Among ten studies which examined the relationship between VDR polymorphisms and cancer prognosis, five found significant associations $[165,180,186-188]$ and five did not [161, 189-192]. In breast cancer patients, the TaqI and BsmI polymorphisms were not significantly associated with prognosis [161, 191]. 
Vitamin D deficiency has also been linked to musculoskeletal disorders, including knee osteoarthritis [193]. In addition, severe vitamin $\mathrm{D}$ deficiency (serum 25(OH)D $<12 \mathrm{ng} / \mathrm{mL}$ or $<29 \mathrm{nmol} / \mathrm{L}$ ) was associated with significantly more joint pain among postmenopausal women [194]. Joint symptoms are a common side effect of aromatase inhibitors (AIs) $[195,196]$, which have become the standard of care for postmenopausal endocrine-sensitive breast cancer. This AIinduced arthralgia syndrome has been associated with low 25(OH)D blood levels [197, 198]. Clinical trials have reported improvements in joint pain related to AIs among breast cancer patients who achieved circulating $25(\mathrm{OH}) \mathrm{D}$ levels of greater than $40 \mathrm{ng} / \mathrm{mL}$ (or $100 \mathrm{nmol} / \mathrm{L}$ ) [198] and $66 \mathrm{ng} / \mathrm{mL}$ (or $218 \mathrm{nmol} / \mathrm{L}$ ) [199]. However, results from these nonrandomized studies need to be confirmed in placebo-controlled trials. In addition, one should take into account the recent Institute of Medicine (IOM) report, which raised concerns about the potential negative health effects associated with serum $25(\mathrm{OH}) \mathrm{D}$ above $50 \mathrm{ng} / \mathrm{mL}$ (or $125 \mathrm{nmol} / \mathrm{L}$ ) [11].

To determine the feasibility of conducting a randomized controlled trial of vitamin D supplementation in women with early stage breast cancer, Cescon et al. found that over $80 \%$ of these women were taking vitamin $\mathrm{D}$ supplements at a median dose of $>1,200$ IU daily and they had a median serum $25(\mathrm{OH}) \mathrm{D}$ of $34.2 \mathrm{ng} / \mathrm{mL}$ (or $85.5 \mathrm{nmol} / \mathrm{L}$ ), which is already in the sufficient range [200]. Therefore, a phase III trial of vitamin $\mathrm{D}$ supplementation in this patient population may not be feasible.

\section{Dosing and Toxicity of Vitamin D Supplements}

Vitamin D deficiency is often defined as a circulating 25hydroxyvitamin D (25(OH)D) level of less than $20 \mathrm{ng} / \mathrm{mL}$ (or $50 \mathrm{nmol} / \mathrm{L}$ ) [201-203]. Sufficient blood concentrations of $25(\mathrm{OH}) \mathrm{D}$ generally focus on bone health, with a common definition of an optimal level of $\geq 30$ or $32 \mathrm{ng} / \mathrm{mL}$ ( $\geq 75$ or $80 \mathrm{nmol} / \mathrm{L}$ ) which maximally suppresses serum parathyroid hormone (PTH). By these standards, the majority of the European and US populations are vitamin D insufficient or deficient.

A recent meta-analysis found that low vitamin D was associated with higher cancer mortality and that intake of standard doses of vitamin D supplements (with average daily doses ranging from $300 \mathrm{IU}$ to 2,000 IU) was associated with a decrease in total mortality [204]. The current recommended dietary allowance (RDA) of vitamin D is $600 \mathrm{IU}$ per day for those of 70 years or younger and $800 \mathrm{IU}$ per day after the age of 70, but some argue that these doses are still too low to benefit public health. Based upon pooled analysis from two large studies conducted in the US and UK, women with serum $25(\mathrm{OH}) \mathrm{D}$ levels greater than $50 \mathrm{ng} / \mathrm{mL}$ (or $125 \mathrm{nmol} / \mathrm{L}$ ) had a $50 \%$ lower risk of breast cancer compared to women with vitamin D deficiency [205]. Oral daily intake of 1,000 IU of vitamin D increases circulating $25(\mathrm{OH}) \mathrm{D}$ levels by about $10 \mathrm{ng} / \mathrm{mL}$ (or $25 \mathrm{nmol} / \mathrm{L}$ ) [206]. However, not all individuals exhibit the same response to vitamin $\mathrm{D}$ supplementation. The greatest response to vitamin $\mathrm{D}$ supplements was observed among those who had the lowest baseline $25(\mathrm{OH}) \mathrm{D}$ blood levels [207]. Given the high prevalence of vitamin D deficiency in the general population, in order to raise serum $25(\mathrm{OH}) \mathrm{D}$ above $50 \mathrm{ng} / \mathrm{mL}$ ( or $125 \mathrm{nmol} / \mathrm{L}$ ), the putative target level for breast cancer risk reduction, individuals would have to consume about $3000-4000$ IU daily, which is still below the current upper safety limit set by the Institute of Medicine (IOM).

In recent years, accumulating evidence suggests that daily doses as high as 10,000 IU are safe. For example, in healthy subjects at a northerly latitude, cholecalciferol 4000 IU daily for 5 months caused no harm and raised vitamin D levels to the desirable level in $88 \%$ of subjects [208]. In a review of clinical trial data on the safety of high-dose vitamin $\mathrm{D}_{3}$, the authors concluded that the absence of toxicity in trials conducted in healthy adults that used vitamin $\mathrm{D}$ doses $\geq 10,000 \mathrm{IU}$ daily supports the selection of this value as the tolerable upper intake level [209].

However, some observational studies have found Ushaped relationships between cancer incidence rates and serum 25(OH)D levels [210-212]. Observational data suggests that the lowest all-cause mortality occurred at moderate serum 25(OH)D levels, with increased mortality risk at both low and high levels [213]. In the National Health and Nutrition Examination Survey (NHANES) III with a median followup of 8.7 years, serum 25(OH)D below $17.8 \mathrm{ng} / \mathrm{mL}$ (or $44.5 \mathrm{nmol} / \mathrm{L}$ ) was associated with a $26 \%$ increase in allcause mortality, but there was a possible increased risk above $32.1 \mathrm{ng} / \mathrm{mL}$ (or $80.3 \mathrm{nmol} / \mathrm{L}$ ) [213]. Observations from a breast cancer cohort suggest that survival may be optimal for women with $25(\mathrm{OH}) \mathrm{D}$ blood levels in the range of 32$44 \mathrm{ng} / \mathrm{mL}$ (or $80-110 \mathrm{nmol} / \mathrm{L}$ ) [173]. Serum 25(OH)D above this range was associated with a trend toward a higher risk of death among breast cancer patients. This U-shaped association was also observed in two cohort studies of $25(\mathrm{OH}) \mathrm{D}$ blood levels in relation to colorectal and prostate cancer risk [211, 214], and a similar nonlinear relationship was found between vitamin $\mathrm{D}$ status and risk of cardiovascular disease [215]. However, the statistical power to investigate risk at very high levels of serum $25(\mathrm{OH}) \mathrm{D}$ was very low.

Vitamin D toxicities, including hypercalcemia, hypercalciuria, bone demineralization, and nephrocalcinosis, are rare and generally only occur when serum $25(\mathrm{OH}) \mathrm{D}$ concentrations rise above $150 \mathrm{ng} / \mathrm{mL}$ (or $375 \mathrm{nmol} / \mathrm{L}$ ) [216]. In addition, the Women's Health Initiative (WHI) randomized controlled trial found a $17 \%$ increase in the incidence of kidney stones with calcium and vitamin D supplementation compared to placebo (2.5\% versus $2.1 \%$ ) [217]. Therefore, the potential benefits of vitamin D supplementation for chronic disease prevention need to be carefully weighed against possible harms.

\section{Clinical Trials of Vitamin D}

Clinical trials have been conducted using the dietary supplement, vitamin $\mathrm{D}_{3}$ (cholecalciferol), which is a precursor to calcitriol, the active metabolite. Administering vitamin $\mathrm{D}_{3}$ to raise serum 25 -hydroxyvitamin $\mathrm{D}(25(\mathrm{OH}) \mathrm{D})$ levels may allow for local production of calcitriol in target tissues, with 
a lower risk of hypercalcemia, hypercalciuria, and kidney stones. A meta-analysis was conducted of eighteen randomized controlled trials of vitamin D supplementation (doses ranging from 300 to 2000 IU daily), which included over 57,000 participants and had fracture incidence as the main primary outcome [204]. The study demonstrated that allcause mortality was reduced by $7 \%$ in the vitamin $\mathrm{D}$ group $(\mathrm{HR}=0.93,95 \% \mathrm{CI}=0.87-0.99)$. Another analysis of nineteen randomized controlled trials of vitamin $\mathrm{D}$ with or without calcium supplementation, including 16 trials with fracture outcomes and 3 with cancer as the primary endpoint, found insufficient evidence to support vitamin D supplementation for cancer prevention [218]. Of note, most trial participants were postmenopausal women over the age of 65 years.

Two large randomized placebo-controlled trials in postmenopausal women examined the effect of combined calcium and vitamin D on cancer incidence. In the Women's Health Initiative (WHI) clinical trial, over 36,000 postmenopausal women were randomized to $1000 \mathrm{mg}$ of calcium carbonate and $400 \mathrm{IU}$ of vitamin $\mathrm{D}_{3}$ or matching placebo. After a mean followup of 7 years, breast and colorectal cancer incidence did not differ between the two groups [90, 219]. However, personal supplementation with vitamin D (up to 600 IU per day) was allowed, which may have dampened the ability to differentiate between the active and control arms. Women with the lowest baseline intake of vitamin $\mathrm{D}$ had a modest reduction (21\%) in breast cancer risk with supplement use. In a nested case-control study, baseline serum $25(\mathrm{OH}) \mathrm{D}$ was inversely associated with breast cancer risk $(P=0.04)$; however, this association did not persist after adjustment for body mass index (BMI) and physical activity. A reanalysis of the data for colorectal cancer risk found that calcium and vitamin D supplementation was beneficial in women not on concurrent estrogen therapy [220]. Lappe et al. conducted another calcium and vitamin D intervention trial in 1,179 postmenopausal women using vitamin D $1100 \mathrm{IU}$ daily for 4 years [94]. They found a $60 \%$ reduction in overall cancer incidence with calcium plus vitamin D compared to placebo; however, the number of cancer events was small. Neither this trial nor the WHI can distinguish between the effects of calcium and vitamin D. It remains uncertain whether targeting premenopausal women at high risk for breast cancer development or administering higher doses of vitamin $\mathrm{D}$ would have a protective effect on breast cancer risk.

Vitamin D and calcium are metabolically interrelated and highly correlated dietary factors which may influence breast cancer development through a variety of mechanisms [67, 221]. Calcium may also have antitumorigenic properties. A subsequent analysis of randomized controlled trials of vitamin D supplementation with or without calcium suggested that lower mortality was observed with the addition of calcium [222]. However, a population-based case-control study from Germany examined the independent and joint effects of dietary vitamin $\mathrm{D}$ and calcium on premenopausal breast cancer risk [57]. Breast cancer risk was inversely associated with vitamin $\mathrm{D}$, but not calcium intake.

Two studies examined supplementation of vitamin $\mathrm{D}_{3}$ $400 \mathrm{IU}$ per day in breast cancer patients concurrently treated with bisphosphonates $[84,223]$. After one year of supplementation, an increase from a mean of $17 \mathrm{ng} / \mathrm{mL}$ (or $42.4 \mathrm{nmol} / \mathrm{L}$ ) to $19 \mathrm{ng} / \mathrm{mL}$ (or $47.4 \mathrm{nmol} / \mathrm{L}$ ) in serum $25(\mathrm{OH}) \mathrm{D}$ was observed [84]. In both study populations, approximately $60 \%$ of patients remained vitamin D deficient after supplementation [84, 223]. Two other single-arm studies examined supplementation with high doses of vitamin D in breast cancer patients $[199,224]$. One study used a dose of 50,000 IU weekly of vitamin $\mathrm{D}_{3}$ among postmenopausal women starting adjuvant aromatase inhibitor therapy [199]. In a phase II trial in women with metastatic breast cancer, vitamin $\mathrm{D}_{3} 10,000 \mathrm{IU}$ daily administered for 4 months did not have a clinical benefit for breast cancer progression [224]. In these studies, few patients experienced any toxicities from high doses of vitamin D, such as hypercalcemia, hypercalciuria, or nephrocalcinosis. These studies demonstrated that the high doses of vitamin $\mathrm{D}$ were well tolerated and led to a significant increase in $25(\mathrm{OH}) \mathrm{D}$ blood levels.

Calcitriol and its structural analogs have been evaluated as therapeutic agents in cancer patients. Most of the clinical trials were conducted in prostate cancer, with relatively few studies in other malignancies. A modest decrease in serum prostate-specific antigen (PSA) was observed in prostate cancer patients given calcitriol $2-2.5 \mu \mathrm{g}$ daily, indicating a decrease in disease progression $[225,226]$. However, the clinical benefit was small and there was a significant increase in the incidence of renal stones [226]. To overcome these toxicities, intermittent dosing of high-dose calcitriol 3 times a week or once weekly was used $[225,227,228]$. This dosing schedule elicited a clinical response with only transient hypercalcemia and a lower risk of kidney stones.

An alternative strategy to reduce the risk of hypercalcemia with calcitriol is to use noncalcemic vitamin $\mathrm{D}$ analogs. In phase I trials in a total of 58 patients with advanced breast cancer, colorectal cancer, and hepatocellular carcinoma, the calcitriol analog EB1089 (seocalcitol) caused stable disease in 6 patients for over 3 months and partial to complete remission in 2 patients [229, 230].

Calcitriol has been used in combination with other agents in the therapeutic setting. For example, in a phase II trial in patients with metastatic castration-resistant prostate cancer, calcitriol $12 \mu \mathrm{g}, 3$ times per week combined with dexamethasone resulted in a $50 \%$ reduction in PSA in $28 \%$ of patients, with no hypercalcemic adverse events [228]. The addition of carboplatin to this regimen resulted in a PSA response in 13 out of 34 patients with metastatic prostate cancer [231]. The ASCENT (Androgen-independent prostate cancer study of Calcitriol ENhancing Taxotere) trials were among the largest clinical trials evaluating calcitriol in combination with chemotherapy. ASCENT I was a phase IIB randomized controlled trial in advanced prostate cancer of a standard docetaxel regimen with high-dose oral calcitriol $45 \mu \mathrm{g}$ weekly (DN-101, Novacea) [232]. The results of the primary endpoint of PSA response at 6 months was $58 \%$ among patients on DN101 compared to $49 \%$ on placebo $(P=0.16)$. However, there was a significant improvement in the secondary endpoints of overall survival and time to progression. ASCENT II was a larger phase III trial in 953 men with metastatic castrationresistant prostate cancer with overall survival as the primary outcome [233]. The treatment arm of DN-101 with weekly 
TABLE 2: Ongoing trials of vitamin D supplementation.

\begin{tabular}{|c|c|c|c|c|c|c|}
\hline Name & Location & $\begin{array}{c}\text { Study } \\
\text { population, } N\end{array}$ & Dose & Outcomes & Current status & $\begin{array}{c}\text { Year results } \\
\text { expected }\end{array}$ \\
\hline VITAL & US & $\begin{array}{c}20,000 \\
\text { Men, age } 50+ \\
\text { Women, age } 55+\end{array}$ & $2000 \mathrm{IU} / \mathrm{d}$ & $\begin{array}{c}\text { Cancer, } \\
\text { cardiovascular disease }\end{array}$ & Recruiting until 2012 & 2017 \\
\hline ViDA & New Zealand & $\begin{array}{c}5100 \\
\text { Age 50+ }\end{array}$ & $\begin{array}{l}100,000 \mathrm{IU} / \mathrm{mo} \\
(3300 \mathrm{IU} / \mathrm{d})\end{array}$ & $\begin{array}{l}\text { Cardiovascular } \\
\text { disease, respiratory } \\
\text { disease, fracture }\end{array}$ & Recruiting until 2012 & 2017 \\
\hline DOHealth & Europe & $\begin{array}{l}2150 \\
\text { Age } 70+\end{array}$ & $2000 \mathrm{IU} / \mathrm{d}$ & $\begin{array}{l}\text { Blood pressure, } \\
\text { fracture, infectious } \\
\text { disease, cognition, } \\
\text { physical function }\end{array}$ & Recruitment ongoing & 2017 \\
\hline FIND & Finland & $\begin{array}{c}18,000 \\
\text { Men, age 60+ } \\
\text { Women, age 65+ }\end{array}$ & $\begin{array}{l}1600 \mathrm{IU} / \mathrm{d} \\
3200 \mathrm{IU} / \mathrm{d}\end{array}$ & $\begin{array}{c}\text { Cancer, } \\
\text { cardiovascular } \\
\text { disease, diabetes }\end{array}$ & $\begin{array}{l}\text { Starting recruitment in } \\
2013\end{array}$ & 2020 \\
\hline VIDAL & UK & $\begin{array}{c}20,000 \\
\text { Age } 65-84\end{array}$ & $\begin{array}{c}60,000 \mathrm{IU} / \mathrm{mo} \\
(2000 \mathrm{IU} / \mathrm{d})\end{array}$ & $\begin{array}{l}\text { Longevity and other } \\
\text { outcomes }\end{array}$ & $\begin{array}{l}\text { Ongoing recruitment of } \\
1600 \text { for feasibility }\end{array}$ & 2020 \\
\hline
\end{tabular}

docetaxel was compared to a new standard regimen of docetaxel given every 3 weeks. The trial was stopped prematurely due to an excess number of deaths in the DN-101 arm. Further analysis suggested that the asymmetric study design with docetaxel schedules led to improved survival in the control arm, rather than excess calcitriol toxicity in the treatment arm. Other phase II trials with various calcitriol formulations in advanced prostate cancer yielded mixed results [234-236].

The results of clinical trials of parent vitamin $\mathrm{D}_{3}$ (cholecalciferol), calcitriol, and vitamin $\mathrm{D}$ analogs in cancer patients and healthy individuals have yielded inconsistent results. Among prostate cancer patients, those with early recurrent disease with PSA relapse had a halting or slowing of PSA progression, whereas trials in patients with late-stage disease yielded disappointing results. Preclinical data suggests that calcitriol may have a more significant growth inhibitory effect during the early stages of cancer development. Therefore, vitamin $\mathrm{D}$ supplementation may have a more beneficial effect for chemoprevention in the primary prevention setting or to prevent cancer recurrence in the adjuvant setting [237].

\section{Future Directions}

More recent trials assessing moderate to high doses of vitamin D supplements to prevent cancer and other chronic diseases are currently ongoing with results due to be reported within the next 5 years (Table 2) [238]. VITAL (VITamin D and omegA-3 fatty acids triaL) is being conducted in the US and is randomizing 20,000 healthy men and women to either vitamin $\mathrm{D}_{3} 2000 \mathrm{IU}$ daily, omega-3 fatty acids $1000 \mathrm{mg}$ daily, the combination or placebo for 5 years. The main outcomes are cancer incidence, as well as cardiovascular disease, stroke, and diabetes. The trial is due to complete enrollment at the end of 2012, but results are not expected for several years. A New Zealand study (ViDA) comparing vitamin $\mathrm{D}_{3}$ 100,000 IU monthly (increased to 200,000 IU monthly in June) to placebo will likely report results in 2017. A Finnish study randomizing 18,000 elderly men and women to vitamin
$\mathrm{D}_{3} 1600 \mathrm{IU}$ daily, $3200 \mathrm{IU}$ daily, or matching placebo will begin enrollment in 2013. In the UK, the VIDAL (VItamin $\mathrm{D}$ And Longevity) trial is examining an intermittent highdose vitamin D regimen (60,000 IU monthly) on all-cause mortality. However, none of these trials are screening for low $25(\mathrm{OH}) \mathrm{D}$ blood levels at baseline for eligibility and perhaps the benefits may be limited to those with vitamin $\mathrm{D}$ deficiency. In addition, all of these ongoing trials are allowing personal supplement use with low-dose vitamin D (up to 800 IU daily), which will make it more difficult to distinguish between the active and control arms.

\section{Conclusions}

While a considerable amount has been learned in the past few years, much remains unknown about the use of vitamin D for the prevention or treatment of breast cancer. An inverse association between vitamin $\mathrm{D}$ status and breast cancer risk was apparent in the majority of studies that included serum 25(OH)D measurements. Almost all of these studies looked at a single assessment of $25(\mathrm{OH}) \mathrm{D}$ blood levels. When serum was taken prediagnostically, typically no association was found, whereas an inverse association was noted in postdiagnostic samples.

Given the limited dietary sources of vitamin D and the increased risk of skin cancer with solar exposure, vitamin D supplementation may be the safest method to improve vitamin $\mathrm{D}$ status. In recent clinical trials, investigators noted an increase in levels of vitamin D with supplementation, but only in those women who were given high dose supplements. In women who were given standard doses of 400-600 IU per day, no substantial change in serum $25(\mathrm{OH}) \mathrm{D}$ was observed and the majority remained in the insufficient range [84, 90, 223]. However, if effective for breast cancer prevention, the optimal dosage of vitamin D supplementation has yet to be determined. In addition, the target population for supplementation based upon the degree of breast cancer risk, meno- 
pausal status, and baseline 25(OH)D blood levels remains unclear.

In spite of the substantial literature on the topic of vitamin $\mathrm{D}$ and breast cancer risk and survival, future studies need to focus on gaining a better understanding of the biologic effects of vitamin D in breast tissue. If the antitumor effects of vitamin $\mathrm{D}$ are confirmed in human studies, then a more accurate dosage of vitamin D for both prophylactic and therapeutic purposes needs to be established. Based upon the current literature, the Institute of Medicine (IOM) concluded that for cancer and vitamin D, the evidence was "inconsistent and insufficient to inform nutritional requirements" [11]. Therefore, the benefits of routine monitoring of serum 25(OH)D and vitamin $\mathrm{D}$ supplementation for breast cancer prevention or to reduce recurrence among breast cancer survivors are uncertain. Given the high prevalence of vitamin D deficiency among high-risk women and breast cancer survivors [84, $170,239]$ and the relatively low toxicity and low cost of supplementation, vitamin D is a potentially modifiable risk factor to target as a strategy for breast cancer prevention and treatment.

\section{Acknowledgments}

The author would like to acknowledge the support from the National Center for Research Resources (NCRR) Grant no. UL1 RR024156, a component of the NIH and NIH Roadmap for Medical Research, and awards from the American Society of Clinical Oncology and Howard Hughes Medical Institute. The author would also like to acknowledge contributions from Laura Reimers, Julie Campbell, and Davida Kornreich.

\section{References}

[1] B. Fisher, J. P. Costantino, D. L. Wickerham et al., "Tamoxifen for prevention of breast cancer: report of the National Surgical Adjuvant Breast and Bowel Project P-1 study," Journal of the National Cancer Institute, vol. 90, no. 18, pp. 1371-1388, 1998.

[2] V. G. Vogel, J. P. Costantino, D. L. Wickerham et al., "Effects of tamoxifen vs raloxifene on the risk of developing invasive breast cancer and other disease outcomes: The NSABP Study of Tamoxifen and Raloxifene (STAR) P-2 trial," Journal of the American Medical Association, vol. 295, no. 23, pp. 2727-2741, 2006.

[3] P. E. Goss, J. N. Ingle, J. E. Ales-Martinez et al., "Exemestane for breast-cancer prevention in postmenopausal women," The New England Journal of Medicine, vol. 364, pp. 2381-2391, 2011.

[4] G. P. Webb, Dietary Supplements and Functional Foods, Blackwell, Oxford, UK, 2nd edition, 2011.

[5] F. L. Apperly, "The relation of solar radiation to cancer mortality in North America," Cancer Research, vol. 1, pp. 191-195, 1941.

[6] G. P. Studzinski and D. C. Moore, "Sunlight—can it prevent as well as cause cancer?" Cancer Research, vol. 55, no. 18, pp. 40144022, 1995.

[7] E. D. Gorham, F. C. Garland, and C. F. Garland, "Sunlight and breast cancer incidence in the USSR," International Journal of Epidemiology, vol. 19, no. 4, pp. 820-824, 1990.

[8] F. C. Garland, C. F. Garland, E. D. Gorham, and J. F. Young, "Geographic variation in breast cancer mortality in the United
States: a hypothesis involving exposure to solar radiation," Preventive Medicine, vol. 19, no. 6, pp. 614-622, 1990.

[9] W. J. Blot, J. F. Fraumeni, and B. J. Stone, "Geographic patterns of breast cancer in the United States," Journal of the National Cancer Institute, vol. 59, no. 5, pp. 1407-1411, 1977.

[10] W. Chen, M. Clements, B. Rahman, S. Zhang, Y. Qiao, and B. K. Armstrong, "Relationship between cancer mortality/incidence and ambient ultraviolet B irradiance in China," Cancer Causes and Control, vol. 21, no. 10, pp. 1701-1709, 2010.

[11] Institute of Medicine, Dietary Reference Intakes For Calcium and Vitamin D, National Academic Press, Washington, DC, USA, 2011.

[12] R. R. Eitenmiller, L. Ye, and W. O. Landen, Vitamin Analysis for the Health and Food Sciences, CRC Press, Boca Raton, Fla, USA, 2nd edition, 2008.

[13] E. Giovannucci, "The epidemiology of vitamin D and cancer incidence and mortality: a review (United States)," Cancer Causes and Control, vol. 16, no. 2, pp. 83-95, 2005.

[14] S. Nesby-O’Dell, K. S. Scanlon, M. E. Cogswell et al., "Hypovitaminosis D prevalence and determinants among African American and white women of reproductive age: Third National Health and Nutrition Examination Survey, 1988-1994," American Journal of Clinical Nutrition, vol. 76, no. 1, pp. 187-192, 2002.

[15] E. Giovannucci, "Vitamin D status and cancer incidence and mortality," Advances in Experimental Medicine and Biology, vol. 624, pp. 31-42, 2008.

[16] A. Zittermann, "Vitamin D: cholecalciferol," in Vitamins in the Prevention of Human Disease, W. Hermann and R. Obeid, Eds., pp. 363-395, De Gruyter, Homburg, Germany, 2011.

[17] M. Hewison and J. S. Adams, "Extra-renal 1alpha-hydroxylase activity and human disease," in Vitamin D, D. Feldman, J. W. Pike, and F. H. Glorieux, Eds., pp. 1379-1400, Elsevier, San Diego, Calif, USA, 2nd edition, 2005.

[18] H. L. Newmark, R. P. Heaney, and P. A. Lachance, "Should calcium and vitamin $\mathrm{D}$ be added to the current enrichment program for cereal-grain products?" American Journal of Clinical Nutrition, vol. 80, no. 2, pp. 264-270, 2004.

[19] G. G. Schwartz, L. W. Whitlatch, T. C. Chen, B. L. Lokeshwar, and M. F. Holick, "Human prostate cells synthesize 1,25-dihydroxyvitamin D3 from 25- hydroxyvitamin D3," Cancer Epidemiology Biomarkers and Prevention, vol. 7, no. 5, pp. 391-395, 1998.

[20] M. J. Larriba, N. Valle, S. Alvarez, and A. Munoz, "Vitamin D3 and colorectal cancer," in Hormonal Carcinovenesis V, J. J. Li, S. A. Li, S. Mohla, H. Rochefort, and T. Maudelonde, Eds., pp. 271-280, Springer, New York, NY, USA, 2008.

[21] D. Feldman, P. J. Malloy, A. V. Krishnan, and E. Balint, "Vitamin D: biology, action, and clinical implications," in Osteoporosis, R. Marcus, D. Feldman, D. A. Nelson, and C. J. Rosen, Eds., Academic, San Diego, Calif, USA, 3rd edition, 2008.

[22] S. Swami, A. V. Krishnan, D. M. Peehl, and D. Feldman, "Genistein potentiates the growth inhibitory effects of 1,25- dihydroxyvitamin D3 in DU145 human prostate cancer cells: role of the direct inhibition of CYP24 enzyme activity," Molecular and Cellular Endocrinology, vol. 241, no. 1-2, pp. 49-61, 2005.

[23] S. Masuda and G. Jones, "Promise of vitamin D analogues in the treatment of hyperproliferative conditions," Molecular Cancer Therapeutics, vol. 5, no. 4, pp. 797-808, 2006.

[24] C. Carlberg and T. W. Dunlop, "The impact of chromatin organization of vitamin D target genes," Anticancer Research, vol. 26, no. 4, pp. 2637-2645, 2006. 
[25] K. W. Colston and C. M. Hansen, "Mechanisms implicated in the growth regulatory effects of vitamin D in breast cancer," Endocrine-Related Cancer, vol. 9, no. 1, pp. 45-59, 2002.

[26] J. Welsh, "Vitamin D and breast cancer: insights from animal models," The American Journal of Clinical Nutrition, vol. 80, pp. 1721S-1724S, 2004.

[27] D. Matthews, E. LaPorta, G. M. Zinser, C. J. Narvaez, and J. Welsh, "Genomic vitamin D signaling in breast cancer: insights from animal models and human cells," Journal of Steroid Biochemistry and Molecular Biology, vol. 121, no. 1-2, pp. 362-367, 2010.

[28] T. Cordes, D. Fischer, M. Thill, S. Becker, M. Friedrich, and D. Salehin, "Vitamin D-1 $\alpha$-hydroxylase and vitamin D-24hydroxylase in benign and malign breast tissue," European Journal of Gynaecological Oncology, vol. 31, no. 2, pp. 151-155, 2010.

[29] N. Lopes, B. Sousa, D. Martins et al., "Alterations in Vitamin D signalling and metabolic pathways in breast cancer progression: a study of VDR, CYP27B1 and CYP24A1 expression in benign and malignant breast lesions Vitamin D pathways unbalanced in breast lesions," BMC Cancer, vol. 10, article 483, 2010.

[30] M. J. Larriba and A. Munoz, "Mechanisms of resistance to vitamin D action in human cancer cells," in Vitamin D: Physiology, Molecular Biology, and Clinical Applications, M. F. Holick, Ed., pp. 325-333, Humana Press, New York, NY, USA, 2010.

[31] J. Thorne and M. J. Campbell, "The molecular cancer biology of the VDR," in Vitamin D and Cancer, D. L. Trump and C. S. Johnson, Eds., pp. 25-52, Springer, New York, NY, USA, 2011.

[32] M. D. Althuis, J. H. Fergenbaum, M. Garcia-Closas, L. A. Brinton, M. P. Madigan, and M. E. Sherman, "Etiology of hormone receptor-defined breast cancer: a systematic review of the literature," Cancer Epidemiology Biomarkers and Prevention, vol. 13, no. 10, pp. 1558-1568, 2004.

[33] X. Peng, M. Hawthorne, A. Vaishnav, R. St-Arnaud, and R. G. Mehta, "25-Hydroxyvitamin D3 is a natural chemopreventive agent against carcinogen induced precancerous lesions in mouse mammary gland organ culture," Breast Cancer Research and Treatment, vol. 113, no. 1, pp. 31-41, 2009.

[34] S. Swami, A. V. Krishnan, J. Y. Wang et al., "Dietary vitamin D(3) and 1, 25-dihydroxyvitamin $\mathrm{D}$ (3) (calcitriol) exhibit equivalent anticancer activity in mouse xenograft models of breast and prostate cancer," in Endocrinology, vol. 153, pp. 2576-2587, 2012.

[35] H. J. Lee, S. Paul, N. Atalla et al., "Gemini vitamin D analogues inhibit estrogen receptor-positive and estrogen receptor-negative mammary tumorigenesis without hypercalcemic toxicity," Cancer Prevention Research, vol. 1, no. 6, pp. 476-484, 2008.

[36] J. Welsh, J. A. Wietzke, G. M. Zinser, B. Byrne, K. Smith, and C. J. Narvaez, "Vitamin D-3 receptor as a target for breast cancer prevention," Journal of Nutrition, vol. 133, no. 7, pp. 2425S2433S, 2003.

[37] K. K. Deeb, D. L. Trump, and C. S. Johnson, "Vitamin D signalling pathways in cancer: potential for anticancer therapeutics," Nature Reviews Cancer, vol. 7, no. 9, pp. 684-700, 2007.

[38] A. Stoica, M. Saceda, A. Fakhro, H. B. Solomon, B. D. Fenster, and M. B. Martin, "Regulation of estrogen receptor-alpha gene expression by 1, 25-dihydroxyvitamin D in MCF-7 cells," in Journal of Cellular Biochemistry, vol. 75, pp. 640-651, 1999.

[39] S. Swami, A. V. Krishnan, and D. Feldman, "1 $\alpha$,25-Dihydroxyvitamin D3 down-regulates estrogen receptor abundance and suppresses estrogen actions in MCF-7 human breast cancer cells," Clinical Cancer Research, vol. 6, no. 8, pp. 3371-3379, 2000.
[40] A. V. Krishnan, S. Swami, L. Peng, J. Wang, J. Moreno, and D. Feldman, "Tissue-selective regulation of aromatase expression by calcitriol: implications for breast cancer therapy," Endocrinology, vol. 151, no. 1, pp. 32-42, 2010.

[41] H. Matsumoto, Y. Iino, Y. Koibuchi et al., "Antitumor effect of 22-oxacalcitriol on estrogen receptor-negative MDA-MB-231 tumors in athymic mice," Oncology Reports, vol. 6, no. 2, pp. 349-352, 1999.

[42] E. A. Hussain, R. R. Mehta, R. Ray, T. K. Das Gupta, and R. G. Mehta, "Efficacy and mechanism of action of lalpha-hydroxy24-ethyl-cholecalciferol (1alpha[OH]D5) in breast cancer prevention and therapy," Recent Results in Cancer Research, vol. 164, pp. 393-411, 2003.

[43] A. V. Krishnan and D. Feldman, "Mechanisms of the anti-cancer and anti-inflammatory actions of vitamin D," Annual Review of Pharmacology and Toxicology, vol. 51, pp. 311-336, 2011.

[44] J. Moreno, A. V. Krishnan, S. Swami, L. Nonn, D. M. Peehl, and D. Feldman, "Regulation of prostaglandin metabolism by calcitriol attenuates growth stimulation in prostate cancer cells," Cancer Research, vol. 65, no. 17, pp. 7917-7925, 2005.

[45] A. M. H. Brodie, Q. Lu, B. J. Long et al., "Aromatase and COX2 expression in human breast cancers," Journal of Steroid Biochemistry and Molecular Biology, vol. 79, no. 1-5, pp. 41-47, 2001.

[46] R. W. Brueggemeier, A. L. Quinn, M. L. Parrett, F. S. Joarder, R. E. Harris, and F. M. Robertson, "Correlation of aromatase and cyclooxygenase gene expression in human breast cancer specimens," Cancer Letters, vol. 140, no. 1-2, pp. 27-35, 1999.

[47] M. Ben-Shoshan, S. Amir, D. T. Dang, L. H. Dang, Y. Weisman, and N. J. Mabjeesh, "1 $1 \alpha, 25$-dihydroxyvitamin D3 (Calcitriol) inhibits hypoxia-inducible factor-1/vascular endothelial growth factor pathway in human cancer cells," Molecular Cancer Therapeutics, vol. 6, no. 4, pp. 1433-1439, 2007.

[48] I. Chung, G. Han, M. Seshadri et al., "Role of vitamin D receptor in the antiproliferative effects of calcitriol in tumor-derived endothelial cells and tumor angiogenesis in vivo," Cancer Research, vol. 69, no. 3, pp. 967-975, 2009.

[49] D. J. Mantell, P. E. Owens, N. J. Bundred, E. B. Mawer, and A. E. Canfield, "1 $\alpha, 25$-Dihydroxyvitamin D3 inhibits angiogenesis in vitro and in vivo," Circulation Research, vol. 87, no. 3, pp. 214$220,2000$.

[50] Y. Ma, W. D. Yu, P. A. Hershberger et al., " $1 \alpha, 25$-Dihydroxyvitamin D3 potentiates cisplatin antitumor activity by p73 induction in a squamous cell carcinoma model," Molecular Cancer Therapeutics, vol. 7, no. 9, pp. 3047-3055, 2008.

[51] M. Chaudhary, S. Sundaram, C. Gennings, H. Carter, and D. A. Gewirtz, "The vitamin D3 analog, ILX-23-7553, enhances the response to Adriamycin and irradiation in MCF-7 breast tumor cells," Cancer Chemotherapy and Pharmacology, vol. 47, no. 5, pp. 429-436, 2001.

[52] D. L. Trump, K. K. Deeb, and C. S. Johnson, "Vitamin D: considerations in the continued development as an agent for cancer prevention and therapy," Cancer Journal, vol. 16, no. 1, pp. 1-9, 2010.

[53] H. Van Der Rhee, J. W. Coebergh, and E. De Vries, "Sunlight, vitamin D and the prevention of cancer: a systematic review of epidemiological studies," European Journal of Cancer Prevention, vol. 18, no. 6, pp. 458-475, 2009.

[54] A. Simard, J. Vobecky, and J. S. Vobecky, "Vitamin D deficiency and cancer of the breast: an unprovocative ecological hypothesis," Canadian Journal of Public Health, vol. 82, no. 5, pp. 300303, 1991. 
[55] N. Potischman, C. A. Swanson, R. J. Coates et al., "Intake of food groups and associated micronutrients in relation to risk of earlystage breast cancer," in International Journal of Cancer, vol. 82, pp. 315-321, 1999.

[56] F. Levi, C. Pasche, F. Lucchini, and C. L. Vecchia, "Dietary intake of selected micronutrients and breast-cancer risk," International Journal of Cancer, vol. 91, no. 2, pp. 260-263, 2001.

[57] S. Abbas, J. Linseisen, and J. Chang-Claude, "Dietary vitamin D and calcium intake and premenopausal breast cancer risk in a german case-control study," Nutrition and Cancer, vol. 59, no. 1, pp. 54-61, 2007.

[58] M. Rossi, J. K. McLaughlin, P. Lagiou et al., "Vitamin D intake and breast cancer risk: a case-control study in Italy," Annals of Oncology, vol. 20, no. 2, pp. 374-378, 2009.

[59] L. N. Anderson, M. Cotterchio, R. Vieth, and J. A. Knight, "Vitamin D and calcium intakes and breast cancer risk in preand postmenopausal women," American Journal of Clinical Nutrition, vol. 91, no. 6, pp. 1699-1707, 2010.

[60] J. A. Knight, M. Lesosky, H. Barnett, J. M. Raboud, and R. Vieth, "Vitamin D and reduced risk of breast cancer: a populationbased case-control study," Cancer Epidemiology Biomarkers and Prevention, vol. 16, no. 3, pp. 422-429, 2007.

[61] T. Kawase, K. Matsuo, T. Suzuki et al., "Association between vitamin $\mathrm{D}$ and calcium intake and breast cancer risk according to menopausal status and receptor status in Japan," Cancer Science, vol. 101, no. 5, pp. 1234-1240, 2010.

[62] M. S. Lee, Y. C. Huang, M. L. Wahlqvist et al., "Vitamin d decreases risk of breast cancer in premenopausal women of normal weight in subtropical Taiwan," Journal of Epidemiology, vol. 21, no. 2, pp. 87-94, 2011.

[63] K. M. Blackmore, M. Lesosky, H. Barnett, J. M. Raboud, R. Vieth, and J. A. Knight, "Vitamin D from dietary intake and sunlight exposure and the risk of hormone-receptor-defined breast cancer," American Journal of Epidemiology, vol. 168, no. 8, pp. 915-924, 2008.

[64] E. M. John, G. G. Schwartz, D. M. Dreon, and J. Koo, "Vitamin D and breast cancer risk: The NHANES I epidemiologic follow-up study, 1971-1975 to 1992," Cancer Epidemiology Biomarkers and Prevention, vol. 8, no. 5, pp. 399-406, 1999.

[65] M. H. Shin, M. D. Holmes, S. E. Hankinson, K. Wu, G. A. Colditz, and W. C. Willett, "Intake of dairy products, calcium, and vitamin D and risk of breast cancer," Journal of the National Cancer Institute, vol. 94, no. 17, pp. 1301-1311, 2002.

[66] A. Lindsay Frazier, L. Li, E. Cho, W. C. Willett, and G. A. Colditz, "Adolescent diet and risk of breast cancer," Cancer Causes and Control, vol. 15, no. 1, pp. 73-82, 2004.

[67] M. L. McCullough, C. Rodriguez, W. R. Diver et al., "Dairy, calcium, and vitamin D intake and postmenopausal breast cancer risk in the cancer prevention study II nutrition cohort," Cancer Epidemiology Biomarkers and Prevention, vol. 14, no. 12, pp. 2898-2904, 2005.

[68] J. Lin, J. E. Manson, I. M. Lee, N. R. Cook, J. E. Buring, and S. M. Zhang, "Intakes of calcium and vitamin D and breast cancer risk in women," Archives of Internal Medicine, vol. 167, no. 10, pp. 1050-1059, 2007.

[69] K. Robien, G. J. Cutler, and D. Lazovich, "Vitamin D intake and breast cancer risk in postmenopausal women: The Iowa Women's Health Study," Cancer Causes and Control, vol. 18, no. 7, pp. 775-782, 2007.

[70] H. Kuper, L. Yang, S. Sandin, M. Lof, H. O. Adami, and E. Weiderpass, "Prospective study of solar exposure, dietary vitamin $\mathrm{D}$ intake, and risk of breast cancer among middle-aged women," Cancer Epidemiology Biomarkers and Prevention, vol. 18, no. 9, pp. 2558-2561, 2009.

[71] K. Edvardsen, M. B. Veierød, M. Brustad, T. Braaten, O. Engelsen, and E. Lund, "Vitamin D-effective solar UV radiation, dietary vitamin $\mathrm{D}$ and breast cancer risk," International Journal of Cancer, vol. 128, no. 6, pp. 1425-1433, 2011.

[72] C. A. Gonzalez, E. Riboli, K. Overvad et al., "Diet and cancer prevention: contributions from the European Prospective Investigation into Cancer and Nutrition (EPIC) study," European Journal of Cancer, vol. 46, no. 14, pp. 2555-2562, 2010.

[73] P. Engel, G. Fagherazzi, S. Mesrine, M. C. Boutron-Ruault, and F. Clavel-Chapelon, "Joint effects of dietary vitamin $\mathrm{d}$ and sun exposure on breast cancer risk: results from the French E3N cohort," Cancer Epidemiology Biomarkers and Prevention, vol. 20, no. 1, pp. 187-195, 2011.

[74] P. Chen, P. Hu, D. Xie, Y. Qin, F. Wang, and H. Wang, "Metaanalysis of vitamin $\mathrm{D}$, calcium and the prevention of breast cancer," Breast Cancer Research and Treatment, vol. 121, no. 2, pp. 469-477, 2010.

[75] H. Reichel, H. P. Koeffler, and A. W. Normal, "The role of the vitamin D endocrine system in health and disease," The New England Journal of Medicine, vol. 320, no. 15, pp. 980-991, 1989.

[76] M. F. Holick, "Vitamin D status: measurement, interpretation, and clinical application," Annals of Epidemiology, vol. 19, no. 2, pp. 73-78, 2009.

[77] L. Yin, N. Grandi, E. Raum, U. Haug, V. Arndt, and H. Brenner, "Meta-analysis: serum vitamin D and breast cancer risk," European Journal of Cancer, vol. 46, no. 12, pp. 2196-2205, 2010.

[78] S. Gandini, M. Boniol, J. Haukka et al., "Meta-analysis of observational studies of serum 25-hydroxyvitamin D levels and colorectal, breast and prostate cancer and colorectal adenoma," International Journal of Cancer, vol. 128, no. 6, pp. 1414-1424, 2011.

[79] S. Abbas, J. Linseisen, T. Slanger et al., "Serum 25-hydroxyvitamin $\mathrm{D}$ and risk of post-menopausal breast cancer-results of a large case-control study," Carcinogenesis, vol. 29, no. 1, pp. 93-99, 2008.

[80] S. Abbas, A. Nieters, J. Linseisen et al., "Vitamin D receptor gene polymorphisms and haplotypes and postmenopausal breast cancer risk," Breast Cancer Research, vol. 10, no. 2, article no. R31, 2008.

[81] S. Abbas, J. Linseisen, T. Slanger et al., "The Gc2 allele of the vitamin $\mathrm{D}$ binding protein is associated with a decreased postmenopausal breast cancer risk, independent of the vitamin D status," Cancer Epidemiology Biomarkers and Prevention, vol. 17, no. 6, pp. 1339-1343, 2008.

[82] D. M. Freedman, S. C. Chang, R. T. Falk et al., "Serum levels of vitamin $\mathrm{D}$ metabolites and breast cancer risk in the prostate, lung, colorectal, and ovarian cancer screening trial," Cancer Epidemiology Biomarkers and Prevention, vol. 17, no. 4, pp. 889894, 2008.

[83] S. Abbas, J. Chang-Claude, and J. Linseisen, "Plasma 25hydroxyvitamin $\mathrm{D}$ and premenopausal breast cancer risk in a German case-control study," International Journal of Cancer, vol. 124, no. 1, pp. 250-255, 2009.

[84] K. D. Crew, E. Shane, S. Cremers, D. J. McMahon, D. Irani, and D. L. Hershman, "High prevalence of vitamin D deficiency despite supplementation in premenopausal women with breast cancer undergoing adjuvant chemotherapy," Journal of Clinical Oncology, vol. 27, no. 13, pp. 2151-2156, 2009.

[85] M. L. McCullough, V. L. Stevens, R. Patel et al., "Serum 25hydroxyvitamin $\mathrm{D}$ concentrations and postmenopausal breast 
cancer risk: a nested case control study in the Cancer Prevention Study-II Nutrition Cohort," Breast Cancer Research, vol. 11, no. 4, article no. R64, 2009.

[86] L. Rejnmark, A. Tietze, P. Vestergaard et al., "Reduced prediagnostic 25-hydroxyvitamin D levels in women with breast cancer: a nested case-control study," Cancer Epidemiology Biomarkers and Prevention, vol. 18, no. 10, pp. 2655-2660, 2009.

[87] M. Almquist, A. G. Bondeson, L. Bondeson, J. Malm, and J. Banjer, "Serum levels of vitamin D, PTH and calcium and breast cancer risk a prospective nested case-control study," International Journal of Cancer, vol. 127, no. 9, pp. 2159-2168, 2010.

[88] P. Engel, G. Fagherazzi, A. Boutten et al., "Serum 25(OH) vitamin D and risk of breast cancer: a nested case-control study from the French E3N cohort," Cancer Epidemiology Biomarkers and Prevention, vol. 19, no. 9, pp. 2341-2350, 2010.

[89] K. D. Crew, M. D. Gammon, S. E. Steck et al., "Association between plasma 25-hydroxyvitamin D and breast cancer risk," in Cancer Prevention Research, vol. 2, pp. 598-604, 2009.

[90] R. T. Chlebowski, K. C. Johnson, C. Kooperberg et al., "Calcium plus vitamin D supplementation and the risk of breast cancer," Journal of the National Cancer Institute, vol. 100, no. 22, pp. 15811591, 2008.

[91] W. B. Grant, "Effect of interval between serum draw and followup period on relative risk of cancer incidence with respect to 25-hydroxyvitamin D level: implications for meta-analyses and setting vitamin D guidelines," Dermatoendocrinol, vol. 3, pp. 199-204, 2011.

[92] J. N. Hofmann, K. Yu, R. L. Horst, R. B. Hayes, and M. P. Purdue, "Long-term variation in serum 25-hydroxyvitamin $\mathrm{d}$ concentration among participants in the prostate, lung, colorectal, and ovarian cancer screening trial," Cancer Epidemiology Biomarkers and Prevention, vol. 19, no. 4, pp. 927-931, 2010.

[93] R. Jorde, M. Sneve, M. Hutchinson, N. Emaus, Y. Figenschau, and G. Grimnes, "Tracking of serum 25-Hydroxyvitamin D levels during 14 years in a population-based study and during 12 months in an intervention study," American Journal of Epidemiology, vol. 171, no. 8, pp. 903-908, 2010.

[94] J. M. Lappe, D. Travers-Gustafson, K. M. Davies, R. R. Recker, and R. P. Heaney, "Vitamin D and calcium supplementation reduces cancer risk: results of a randomized trial," American Journal of Clinical Nutrition, vol. 85, no. 6, pp. 1586-1591, 2007.

[95] W. Zhou, R. S. Heist, G. Liu et al., "Circulating 25-hydroxyvitamin D levels predict survival in early-stage non-small-cell lung cancer patients," Journal of Clinical Oncology, vol. 25, no. 5, pp. 479-485, 2007.

[96] E. R. Bertone-Johnson, W. Y. Chen, M. F. Holick et al., "Plasma 25-hydroxyvitamin D and 1,25-dihydroxyvitamin D and risk of breast cancer," Cancer Epidemiology Biomarkers and Prevention, vol. 14, no. 8, pp. 1991-1997, 2005.

[97] M. Chung, E. M. Balk, M. Brendel et al., "Vitamin D and calcium: a systematic review of health outcomes," Evidence Report, no. 183, pp. 1-420, 2009.

[98] International Agency for Research on Cancer, Vitamin D and Cancer-A Report of the IARC Working Group on Vitamin D, World Health Organization Press, Lyon, France, 2008.

[99] O. P. Heinonen and D. Albanes, "The effect of vitamin E and beta carotene on the incidence of lung cancer and other cancers in male smokers," The New England Journal of Medicine, vol. 330, no. 15, pp. 1029-1035, 1994.

[100] D. Albanes, O. P. Heinonen, P. R. Taylor et al., " $\alpha$-tocopherol and $\beta$-carotene supplements and lung cancer incidence in the alphatocopherol, beta-carotene cancer prevention study: effects of base- line characteristics and study compliance," Journal of the National Cancer Institute, vol. 88, no. 21, pp. 1560-1570, 1996.

[101] G. S. Omenn, G. Goodman, M. Thornquist et al., "The $\beta$-carotene and retinol efficacy trial (CARET) for chemoprevention of lung cancer in high risk populations: smokers and asbestosexposed workers," Cancer Research, vol. 54, no. 7, pp. 2038s2043s, 1994.

[102] B. F. Cole, J. A. Baron, R. S. Sandler et al., "Folic acid for the prevention of colorectal adenomas: a randomized clinical trial," Journal of the American Medical Association, vol. 297, no. 21, pp. 2351-2359, 2007.

[103] E. A. Klein, I. M. Thompson Jr., C. M. Tangen et al., "Vitamin $\mathrm{E}$ and the risk of prostate cancer: the selenium and vitamin E Cancer Prevention Trial (SELECT)," The Journal of the American Medical Association, vol. 306, pp. 1549-1556, 2011.

[104] V. A. McCormack and I. Dos Santos Silva, "Breast density and parenchymal patterns as markers of breast cancer risk: a metaanalysis," Cancer Epidemiology Biomarkers and Prevention, vol. 15, no. 6, pp. 1159-1169, 2006.

[105] N. F. Boyd, H. Guo, L. J. Martin et al., "Mammographic density and the risk and detection of breast cancer," The New England Journal of Medicine, vol. 356, no. 3, pp. 227-236, 2007.

[106] N. F. Boyd, G. A. Lockwood, J. W. Byng, D. L. Tritchler, and M. J. Yaffe, "Mammographic densities and breast cancer risk," Cancer Epidemiology Biomarkers and Prevention, vol. 7, no. 12, pp. 11331144, 1998.

[107] N. F. Boyd, J. W. Byng, R. A. Jong et al., "Quantitative classification of mammographic densities and breast cancer risk: results from the Canadian National Breast Screening Study," Journal of the National Cancer Institute, vol. 87, no. 9, pp. 670-675, 1995.

[108] P. Tehranifar, D. Reynolds, J. Flom et al., "Reproductive and menstrual factors and mammographic density in African American, Caribbean, and white women," Cancer Causes and Control, vol. 22, no. 4, pp. 599-610, 2011.

[109] J. Cuzick, J. Warwick, E. Pinney et al., “Tamoxifen-induced reduction in mammographic density and breast cancer risk reduction: a nested case-control study," Journal of the National Cancer Institute, vol. 103, no. 9, pp. 744-752, 2011.

[110] L. Yaghjyan, G. A. Colditz, and B. Drake, "Vitamin D and mammographic breast density: a systematic review," Cancer Causes and Control, vol. 23, pp. 1-13, 2012.

[111] J. A. Knight, C. M. Vachon, R. A. Vierkant, R. Vieth, J. R. Cerhan, and T. A. Sellers, "No association between 25-hydroxyvitamin D and mammographic density," Cancer Epidemiology Biomarkers and Prevention, vol. 15, no. 10, pp. 1988-1992, 2006.

[112] J. Brisson, S. Bérubé, C. Diorio, M. Sinotte, M. Pollak, and B. Mâsse, "Synchronized seasonal variations of mammographic breast density and plasma 25-hydroxyvitamin D," Cancer Epidemiology Biomarkers and Prevention, vol. 16, no. 5, pp. 929-933, 2007.

[113] A. K. Green, S. E. Hankinson, E. R. Bertone-Johnson, and R. M. Tamimi, "Mammographic density, plasma vitamin D levels and risk of breast cancer in postmenopausal women," International Journal of Cancer, vol. 127, no. 3, pp. 667-674, 2010.

[114] W. Chai, G. Maskarinec, and R. V. Cooney, "Serum 25hydroxyvitamin D levels and mammographic density among premenopausal women in a multiethnic population," European Journal of Clinical Nutrition, vol. 64, no. 6, pp. 652-654, 2010.

[115] M. L. Neuhouser, L. Bernstein, B. W. Hollis et al., "Serum vitamin D and breast density in breast cancer survivors," Cancer Epidemiology Biomarkers and Prevention, vol. 19, no. 2, pp. 412417, 2010. 
[116] C. M. Vachon, L. H. Kushi, J. R. Cerhan, C. C. Kuni, and T. A. Sellers, "Association of diet and mammographic breast density in the Minnesota breast cancer family cohort," Cancer Epidemiology Biomarkers and Prevention, vol. 9, no. 2, pp. 151-160, 2000.

[117] S. Bérubé, C. Diorio, B. Mâsse et al., "Vitamin D and calcium intakes from food or supplements and mammographic breast density," Cancer Epidemiology Biomarkers and Prevention, vol. 14, no. 7, pp. 1653-1659, 2005.

[118] C. Diorio, S. Bérubé, C. Byrne et al., "Influence of insulin-like growth factors on the strength of the relation of vitamin $\mathrm{D}$ and calcium intakes to mammographic breast density," Cancer Research, vol. 66, no. 1, pp. 588-597, 2006.

[119] L. A. Colangelo, B. C. H. Chiu, P. Lopez et al., "A pilot study of vitamin $\mathrm{D}$, calcium, and percent breast density in Hispanic women," Nutrition Research, vol. 26, no. 1, pp. 11-15, 2006.

[120] C. A. Thomson, L. A. Arendell, R. L. Bruhn et al., "Pilot study of dietary influences on mammographic density in pre- and postmenopausal Hispanic and non-Hispanic white women," Menopause, vol. 14, no. 2, pp. 243-250, 2007.

[121] E. R. Bertone-Johnson, R. T. Chlebowski, J. E. Manson et al., "Dietary vitamin D and calcium intake and mammographic density in postmenopausal women," Menopause, vol. 17, no. 6, pp. 1152-1160, 2010.

[122] M. Tseng, C. Byrne, K. A. Evers, and M. B. Daly, "Dietary intake and breast density in high-risk women: a cross-sectional study," Breast Cancer Research, vol. 9, no. 5, article R72, 2007.

[123] G. Mishra, V. McCormack, D. Kuh, R. Hardy, A. Stephen, and I. Dos Santos Silva, "Dietary calcium and vitamin D intakes in childhood and throughout adulthood and mammographic density in a British birth cohort," British Journal of Cancer, vol. 99, no. 9, pp. 1539-1543, 2008.

[124] G. Masala, D. Ambrogetti, M. Assedi, D. Giorgi, M. R. Del Turco, and D. Palli, "Dietary and lifestyle determinants of mammographic breast density: a longitudinal study in a Mediterranean population," International Journal of Cancer, vol. 118, no. 7, pp. 1782-1789, 2006.

[125] S. A. Qureshi, E. Couto, M. Hilsen, S. Hofvind, A. H. Wu, and G. Ursin, "Mammographic density and intake of selected nutrients and vitamins in Norwegian women," Nutrition and Cancer, vol. 63, pp. 1011-1020, 2011.

[126] B. L. Sprague, A. Trentham-Dietz, R. E. Gangnon et al., "The vitamin D pathway and mammographic breast density among postmenopausal women," Breast Cancer Research and Treatment, vol. 131, pp. 255-265, 2012.

[127] T. J. Key, P. N. Appleby, G. K. Reeves et al., "Body mass index, serum sex hormones, and breast cancer risk in postmenopausal women," Journal of the National Cancer Institute, vol. 95, no. 16, pp. 1218-1226, 2003.

[128] J. Wortsman, L. Y. Matsuoka, T. C. Chen, Z. Lu, and M. F. Holick, "Decreased bioavailability of vitamin D in obesity," American Journal of Clinical Nutrition, vol. 72, no. 3, pp. 690-693, 2000.

[129] Z. Lagunova, A. C. Porojnicu, W. B. Grant, Ø. Bruland, and J. E. Moan, "Obesity and increased risk of cancer: does decrease of serum 25-hydroxyvitamin D level with increasing body mass index explain some of the association?" Molecular Nutrition and Food Research, vol. 54, no. 8, pp. 1127-1133, 2010.

[130] E. Amir, R. S. Cecchini, P. A. Ganz et al., "25-Hydroxy vitamin$\mathrm{D}$, obesity, and associated variables as predictors of breast cancer risk and tamoxifen benefit in NSABP-P1," Breast Cancer Research and Treatment, vol. 133, pp. 1077-1088, 2012.

[131] E. R. Bertone-Johnson, A. McTiernan, C. A. Thomson et al., "Vitamin D and calcium supplementation and one-year change in mammographic density in the women's health initiative calcium and vitamin D trial," Cancer Epidemiology, Biomarkers \& Prevention, vol. 21, pp. 462-473, 2012.

[132] R. R. Buras, L. M. Schumaker, F. Davoodi et al., "Vitamin D receptors in breast cancer cells," Breast Cancer Research and Treatment, vol. 31, no. 2-3, pp. 191-202, 1994.

[133] N. J. Rukin and R. C. Strange, "What are the frequency, distribution, and functional effects of vitamin D receptor polymorphisms as related to cancer risk?" Nutrition Reviews, vol. 65, no. 8, pp. S96-S101, 2007.

[134] A. G. Uitterlinden, Y. Fang, J. B. J. Van Meurs, H. A. P. Pols, and J. P. T. M. Van Leeuwen, "Genetics and biology of vitamin D receptor polymorphisms," Gene, vol. 338, no. 2, pp. 143-156, 2004.

[135] L. C. Lowe, M. Guy, J. L. Mansi et al., "Plasma 25-hydroxy vitamin D concentrations, vitamin D receptor genotype and breast cancer risk in a UK Caucasian population," European Journal of Cancer, vol. 41, no. 8, pp. 1164-1169, 2005.

[136] W. Y. Chen, E. R. Bertone-Johnson, D. J. Hunter, W. C. Willett, and S. E. Hankinson, "Associations between polymorphisms in the vitamin D receptor and breast cancer risk," Cancer Epidemiology Biomarkers and Prevention, vol. 14, no. 10, pp. 23352339, 2005.

[137] S. I. Berndt, J. L. Dodson, W. Y. Huang, and K. K. Nicodemus, “A systematic review of vitamin D receptor gene polymorphisms and prostate cancer risk," Journal of Urology, vol. 175, no. 5, pp. 1613-1623, 2006.

[138] H. Arai, K. I. Miyamoto, Y. Taketani et al., "A vitamin D receptor gene polymorphism in the translation initiation codon: effect on protein activity and relation to bone mineral density in Japanese women," Journal of Bone and Mineral Research, vol. 12, no. 6, pp. 915-921, 1997.

[139] M. Guy, L. C. Lowe, D. Bretherton-Watt et al., "Vitamin D receptor gene polymorphisms and breast cancer risk," Clinical Cancer Research, vol. 10, no. 16, pp. 5472-5481, 2004.

[140] D. Bretherton-Watt, R. Given-Wilson, J. L. Mansi, V. Thomas, N. Carter, and K. W. Colston, "Vitamin D receptor gene polymorphisms are associated with breast cancer risk in a UK Caucasian population," British Journal of Cancer, vol. 85, no. 2, pp. 171-175, 2001.

[141] S. A. Ingles, D. G. Garcia, W. Wang et al., "Vitamin D receptor genotype and breast cancer in Latinas (United States)," Cancer Causes and Control, vol. 11, no. 1, pp. 25-30, 2000.

[142] J. E. Curran, T. Vaughan, R. A. Lea, S. R. Weinstein, N. A. Morrison, and L. R. Griffiths, "Association of A vitamin D receptor polymorphism with sporadic breast cancer development," International Journal of Cancer, vol. 83, pp. 723-726, 1999.

[143] E. M. John, G. G. Schwartz, J. Koo, W. Wang, and S. A. Ingles, "Sun exposure, vitamin D receptor gene polymorphisms, and breast cancer risk in a multiethnic population," American Journal of Epidemiology, vol. 166, no. 12, pp. 1409-1419, 2007.

[144] M. L. McCullough, V. L. Stevens, W. R. Diver et al., "Vitamin D pathway gene polymorphisms, diet, and risk of postmenopausal breast cancer: A Nested Case-Control Study," Breast Cancer Research, vol. 9, no. 1, article R9, 2007.

[145] M. Guy, L. C. Lowe, D. Bretherton-Watt, J. L. Mansi, and K. W. Colston, "Approaches to evaluating the association of vitamin D receptor gene polymorphisms with breast cancer risk," Recent Results in Cancer Research, vol. 164, pp. 43-54, 2003. 
[146] S. Raimondi, H. Johansson, P. Maisonneuve, and S. Gandini, "Review and meta-analysis on vitamin D receptor polymorphisms and cancer risk," Carcinogenesis, vol. 30, no. 7, pp. 11701180, 2009.

[147] M. L. Slattery, "Vitamin D receptor gene (VDR) associations with cancer," Nutrition Reviews, vol. 65, no. 8, pp. S102-S104, 2007.

[148] L. K. Durrin, R. W. Haile, S. A. Ingles, and G. A. Coetzee, "Vitamin D receptor 3'-untranslated region polymorphisms: lack of effect on mRNA stability," Biochimica et Biophysica Acta, vol. 1453, no. 3, pp. 311-320, 1999.

[149] G. Kerr Whitfield, L. S. Remus, P. W. Jurutka et al., "Functionally relevant polymorphisms in the human nuclear vitamin D receptor gene," Molecular and Cellular Endocrinology, vol. 177, no. 1-2, pp. 145-159, 2001.

[150] B. Trabert, K. E. Malone, J. R. Daling et al., "Vitamin D receptor polymorphisms and breast cancer risk in a large populationbased case-control study of Caucasian and African-American women," Breast Cancer Research, vol. 9, no. 6, article R84, 2007.

[151] M. Ruggiero, S. Pacini, S. Aterini, C. Fallai, C. Ruggiero, and P. Pacini, "Vitamin D receptor gene polymorphism is associated with metastatic breast cancer," Oncology Research, vol. 10, no. 1, pp. 43-46, 1998.

[152] K. Köstner, N. Denzer, C. S. L. Müller, R. Klein, W. Tilgen, and J. Reichrath, "The relevance of Vitamin D Receptor (VDR) gene polymorphisms for cancer: a review of the literature," Anticancer Research, vol. 29, no. 9, pp. 3511-3536, 2009.

[153] N. A. Morrison, Jian Cheng Qi, A. Tokita et al., "Prediction of bone density from vitamin D receptor alleles," Nature, vol. 367, no. 6460, pp. 284-287, 1994.

[154] F. G. Hustmyer, H. F. DeLuca, and M. Peacock, "Apal, Bsml, EcoRV and Taql polymorphisms at the human vitamin D receptor gene locus in Caucasians, Blacks and Asians," Human Molecular Genetics, vol. 2, no. 4, article 487, 1993.

[155] J. Ma, M. J. Stampfer, P. H. Gann et al., "Vitamin D receptor polymorphisms, circulating vitamin D metabolites, and risk of prostate cancer in United States physicians," Cancer Epidemiology Biomarkers and Prevention, vol. 7, no. 5, pp. 385-390, 1998.

[156] P. Sillanpää, A. Hirvonen, V. Kataja et al., "Vitamin D receptor gene polymorphism as an important modifier of positive family history related breast cancer risk," Pharmacogenetics, vol. 14, no. 4, pp. 239-245, 2004.

[157] N. Buyru, A. Tezol, E. Yosunkaya-Fenerci, and N. Dalay, "Vitamin D receptor gene polymorphisms in breast cancer," Experimental and Molecular Medicine, vol. 35, no. 6, pp. 550555, 2003.

[158] P. A. Newcomb, H. Kim, A. Trentham-Dietz, F. Farin, D. Hunter, and K. M. Egan, "Vitamin D receptor polymorphism and breast cancer risk," Cancer Epidemiology, Biomarkers \& Prevention, vol. 11, pp. 1503-1504, 2002.

[159] M. F. Hou, Y. C. Tien, G. T. Lin et al., "Association of vitamin $D$ receptor gene polymorphism with sporadic breast cancer in Taiwanese patients," Breast Cancer Research and Treatment, vol. 74, no. 1, pp. 1-7, 2002.

[160] A. M. Dunning, S. McBride, J. Gregory et al., "No association between androgen or vitamin $\mathrm{D}$ receptor gene polymorphisms and risk of breast cancer," Carcinogenesis, vol. 20, no. 11, pp. 21312135, 1999.

[161] A. C. Lundin, P. Söderkvist, B. Eriksson, M. BergmanJungeström, and S. Wingren, "Association of breast cancer progression with a vitamin D receptor gene polymorphism," Cancer Research, vol. 59, no. 10, pp. 2332-2334, 1999.
[162] C. Diorio, M. Sinotte, J. Brisson, S. Bérube, and M. Pollak, "Vitamin D pathway polymorphisms in relation to mammographic breast density," Cancer Epidemiology Biomarkers and Prevention, vol. 17, no. 9, pp. 2505-2508, 2008.

[163] H. Li, M. J. Stampfer, J. B. W. Hollis et al., "A prospective study of plasma vitamin D metabolites, vitamin D receptor polymorphisms, and prostate cancer," PLoS Medicine, vol. 4, no. 3, article e103, 2007.

[164] K. D. Crew, M. D. Gammon, D. L. Hershman et al., Low Serum 25-Hydroxy Vitamin D and Vitamin D Receptor Polymorphisms are Associated with Increased Breast Cancer Risk, American Society for Bone and Mineral Research, Montreal, Canada, 2008.

[165] E. M. Colin, A. E. A. M. Weel, A. G. Uitterlinden et al., "Consequences of vitamin D receptor gene polymorphisms for growth inhibition of cultured human peripheral blood mononuclear cells by 1,25-dihydroxyvitamin D3," Clinical Endocrinology, vol. 52, no. 2, pp. 211-216, 2000.

[166] P. W. Jurutka, L. S. Remus, G. K. Whitfield et al., "The polymorphic $\mathrm{N}$ terminus in human vitamin $\mathrm{D}$ receptor isoforms influences transcriptional activity by modulating interaction with transcription factor IIB," Molecular Endocrinology, vol. 14, no. 3, pp. 401-420, 2000.

[167] A. G. Uitterlinden, Y. Fang, J. B. J. Van Meurs, H. Van Leeuwen, and H. A. P. Pols, "Vitamin D receptor gene polymorphisms in relation to Vitamin D related disease states," Journal of Steroid Biochemistry and Molecular Biology, vol. 89-90, pp. 187-193, 2004.

[168] J. M. Zmuda, J. A. Cauley, and R. E. Ferrell, "Molecular epidemiology of vitamin D receptor gene variants," Epidemiologic Reviews, vol. 22, no. 2, pp. 203-217, 2000.

[169] T. E. Robsahm, S. Tretli, A. Dahlback, and J. Moan, "Vitamin D3 from sunlight may improve the prognosis of breast-, colonand prostate cancer (Norway)," Cancer Causes and Control, vol. 15, no. 2, pp. 149-158, 2004.

[170] M. L. Neuhouser, B. Sorensen, B. W. Hollis et al., "Vitamin D insufficiency in a multiethnic cohort of breast cancer survivors," American Journal of Clinical Nutrition, vol. 88, no. 1, pp. 133-139, 2008.

[171] P. G. Vashi, K. Trukova, C. A. Lammersfeld, D. P. Braun, and D. Gupta, "Impact of oral vitamin D supplementation on serum 25-hydroxyvitamin D levels in oncology," Nutrition Journal, vol. 9, article 60, 2010

[172] L. J. Peppone, A. J. Huston, M. E. Reid et al., "The effect of various vitamin $\mathrm{D}$ supplementation regimens in breast cancer patients," Breast Cancer Research and Treatment, vol. 127, no. 1, pp. 171-177, 2011.

[173] P. J. Goodwin, M. Ennis, K. I. Pritchard, J. Koo, and N. Hood, "Prognostic effects of 25-hydroxyvitamin D levels in early breast cancer," Journal of Clinical Oncology, vol. 27, no. 23, pp. 37573763,2009

[174] E. Piura, J. W. Chapman, and A. Lipton, "Serum vitamin D and prognosis of postmenopausal breast cancer patients: NCICCTG MA14 trial," in Proceedings of the ASCO Annual Meeting, American Society of Clinical Oncology, 2009.

[175] E. T. Jacobs, C. A. Thomson, S. W. Flatt et al., "Vitamin D and breast cancer recurrence in the Women's Healthy Eating and Living (WHEL) Study," American Journal of Clinical Nutrition, vol. 93, no. 1, pp. 108-117, 2011.

[176] R. S. Heist, W. Zhou, Z. Wang et al., "Circulating 25-hydroxyvitamin $\mathrm{D}, \mathrm{VDR}$ polymorphisms, and survival in advanced 
non-small-cell lung cancer," Journal of Clinical Oncology, vol. 26, no. 34, pp. 5596-5602, 2008.

[177] K. Ng, J. A. Meyerhardt, K. Wu et al., "Circulating 25hydroxyvitamin D levels and survival in patients with colorectal cancer," Journal of Clinical Oncology, vol. 26, no. 18, pp. 29842991, 2008.

[178] K. M. Wesa, A. Cronin, and N. H. Segal, Serum 25-Hydroxyvitamin D and Survival in Colorectacl Cancer: A Retrospective Analysis, American Society of Clinical Oncology, Chicago, Ill, USA, 2010.

[179] S. Tretli, E. Hernes, J. P. Berg, U. E. Hestvik, and T. E. Robsahm, "Association between serum 25(OH)D and death from prostate cancer," British Journal of Cancer, vol. 100, no. 3, pp. 450-454, 2009.

[180] J. A. Newton-Bishop, S. Beswick, J. Randerson-Moor et al., "Serum 25-hydroxyvitamin D3 levels are associated with Breslow thickness at presentation and survival from melanoma," Journal of Clinical Oncology, vol. 27, no. 32, pp. 5439-5444, 2009.

[181] C. Buttigliero, C. Monagheddu, P. Petroni et al., "Prognostic role of vitamin d status and efficacy of vitamin D supplementation in cancer patients: a systematic review," Oncologist, vol. 16, pp. 1215-1227, 2011.

[182] W. B. Grant and A. N. Peiris, "Possible role of serum 25hydroxyvitamin D in black-white health disparities in the United States," Journal of the American Medical Directors Association, vol. 11, no. 9, pp. 617-628, 2010.

[183] S. R. T. Evans, J. Nolla, J. Hanfelt, M. Shabahang, R. J. Nauta, and I. B. Shchepotin, "Vitamin D receptor expression as a predictive marker of biological behavior in human colorectal cancer," Clinical Cancer Research, vol. 4, no. 7, pp. 1591-1595, 1998.

[184] W. Seubwai, C. Wongkham, A. Puapairoj, N. Khuntikeo, and S. Wongkham, "Overexpression of vitamin D receptor indicates a good prognosis for cholangiocarcinoma: implications for therapeutics," Cancer, vol. 109, no. 12, pp. 2497-2505, 2007.

[185] W. Obara, R. Konda, S. Akasaka, S. Nakamura, A. Sugawara, and T. Fujioka, "Prognostic significance of vitamin D receptor and retinoid X receptor expression in renal cell carcinoma," Journal of Urology, vol. 178, no. 4, pp. 1497-1503, 2007.

[186] J. A. Halsall, J. E. Osborne, L. Potter, J. H. Pringle, and P. E. Hutchinson, "A novel polymorphism in the IA promoter region of the vitamin D receptor is associated with altered susceptibilty and prognosis in malignant melanoma," British Journal of Cancer, vol. 91, no. 4, pp. 765-770, 2004.

[187] W. Obara, Y. Suzuki, K. Kato, S. Tanji, R. Konda, and T. Fujioka, "Vitamin D receptor gene polymorphisms are associated with increased risk and progression of renal cell carcinoma in a Japanese population," International Journal of Urology, vol. 14, no. 6, pp. 483-487, 2007.

[188] S. Tamez, C. Norizoe, K. Ochiai et al., "Vitamin D receptor polymorphisms and prognosis of patients with epithelial ovarian cancer," British Journal of Cancer, vol. 101, no. 12, pp. 1957-1960, 2009.

[189] Y. Xu, A. Shibata, J. E. McNeal, T. A. Stamey, D. Feldman, and D. M. Peehl, "Vitamin D receptor start codon polymorphism (FokI) and prostate cancer progression," Cancer Epidemiology Biomarkers and Prevention, vol. 12, no. 1, pp. 23-27, 2003.

[190] H. Williams, I. J. Powell, S. J. Land et al., "Vitamin D receptor gene polymorphisms and disease free survival after radical prostatectomy," Prostate, vol. 61, no. 3, pp. 267-275, 2004.

[191] M. C. Yagmurdur, F. B. Atac, N. Uslu et al., "Clinical importance of vitamin $\mathrm{D}$ receptor gene polymorphism in invasive ductal carcinoma," International Surgery, vol. 94, no. 4, pp. 304-309, 2009.

[192] W. Zhou, R. S. Heist, G. Liu et al., "Polymorphisms of vitamin D receptor and survival in early-stage non-small cell lung cancer patients," Cancer Epidemiology Biomarkers and Prevention, vol. 15, no. 11, pp. 2239-2245, 2006.

[193] T. E. McAlindon, D. T. Felson, Y. Zhang et al., "Relation of dietary intake and serum levels of vitamin $\mathrm{D}$ to progression of osteoarthritis of the knee among participants in the Framingham Study," Annals of Internal Medicine, vol. 125, no. 5, pp. 353359, 1996.

[194] R. T. Chlebowski, K. C. Johnson, D. Lane et al., "25-Hydroxyvitamin $\mathrm{D}$ concentration, vitamin $\mathrm{D}$ intake and joint symptoms in postmenopausal women," Maturitas, vol. 68, no. 1, pp. 73-78, 2011.

[195] K. D. Crew, H. Greenlee, J. Capodice et al., "Prevalence of joint symptoms in postmenopausal women taking aromatase inhibitors for early-stage breast cancer," Journal of Clinical Oncology, vol. 25, no. 25, pp. 3877-3883, 2007.

[196] R. T. Chlebowski, "Aromatase inhibitor-associated arthralgias," Journal of Clinical Oncology, vol. 27, no. 30, pp. 4932-4934, 2009.

[197] N. L. Waltman, C. D. Ott, J. J. Twiss, G. J. Gross, and A. M. Lindsey, "Vitamin D insufficiency and musculoskeletal symptoms in breast cancer survivors on aromatase inhibitor therapy," Cancer Nursing, vol. 32, no. 2, pp. 143-150, 2009.

[198] D. Prieto-Alhambra, M. K. Javaid, S. Servitja et al., "Vitamin $D$ threshold to prevent aromatase inhibitor-induced arthralgia: A Prospective Cohort Study," Breast Cancer Research and Treatment, vol. 125, no. 3, pp. 869-878, 2011.

[199] Q. J. Khan, P. S. Reddy, B. F. Kimler et al., "Effect of vitamin D supplementation on serum 25-hydroxy vitamin D levels, joint pain, and fatigue in women starting adjuvant letrozole treatment for breast cancer," Breast Cancer Research and Treatment, vol. 119, no. 1, pp. 111-118, 2010.

[200] D. W. Cescon, P. A. Ganz, S. Hallak, M. Ennis, B. K. Mills, and P. J. Goodwin, "Feasibility of a randomized controlled trial of vitamin D vs. placebo in recently diagnosed breast cancer patients," Breast Cancer Research and Treatment, vol. 134, no. 2, pp. 759-767, 2012.

[201] M. F. Holick and T. C. Chen, "Vitamin D deficiency: a worldwide problem with health consequences," American Journal of Clinical Nutrition, vol. 87, no. 4, pp. 1080S-1086S, 2008.

[202] M. F. Holick, "Medical progress: vitamin D deficiency," The New England Journal of Medicine, vol. 357, no. 3, pp. 266-281, 2007.

[203] H. A. Bischoff-Ferrari, E. Giovannucci, W. C. Willett, T. Dietrich, and B. Dawson-Hughes, "Estimation of optimal serum concentrations of 25-hydroxyvitamin D for multiple health outcomes," American Journal of Clinical Nutrition, vol. 84, no. 1, pp. 18-28, 2006.

[204] P. Autier and S. Gandini, "Vitamin D supplementation and total mortality: a meta-analysis of randomized controlled trials," Archives of Internal Medicine, vol. 167, no. 16, pp. 1730-1737, 2007.

[205] C. F. Garland, E. D. Gorham, S. B. Mohr et al., "Vitamin D and prevention of breast cancer: pooled analysis," Journal of Steroid Biochemistry and Molecular Biology, vol. 103, no. 3-5, pp. 708711, 2007.

[206] R. P. Heaney, K. M. Davies, T. C. Chen, M. F. Holick, and M. Janet Barger-Lux, "Human serum 25-hydroxycholecalciferol response to extended oral dosing with cholecalciferol," American Journal of Clinical Nutrition, vol. 77, no. 1, pp. 204-210, 2003. 
[207] S. Ish-Shalom, E. Segal, T. Salganik, B. Raz, I. L. Bromberg, and R. Vieth, "Comparison of daily, weekly, and monthly vitamin D3 in ethanol dosing protocols for two months in elderly hip fracture patients," Journal of Clinical Endocrinology and Metabolism, vol. 93, no. 9, pp. 3430-3435, 2008.

[208] R. Vieth, P. C. R. Chan, and G. D. MacFarlane, "Efficacy and safety of vitamin D3 intake exceeding the lowest observed adverse effect level," American Journal of Clinical Nutrition, vol. 73, no. 2, pp. 288-294, 2001.

[209] J. N. Hathcock, A. Shao, R. Vieth, and R. Heaney, "Risk assessment for vitamin D," American Journal of Clinical Nutrition, vol. 85, no. 1, pp. 6-18, 2007.

[210] R. Z. Stolzenberg-Solomon, R. Vieth, A. Azad et al., "A prospective nested case-control study of vitamin D status and pancreatic cancer risk in male smokers," Cancer Research, vol. 66, no. 20, pp. 10213-10219, 2006.

[211] P. Tuohimaa, L. Tenkanen, M. Ahonen et al., "Both high and low levels of blood vitamin D are associated with a higher prostate cancer risk: a longitudinal, nested case-control study in the Nordic countries," International Journal of Cancer, vol. 108, no. 1, pp. 104-108, 2004.

[212] C. C. Abnet, W. Chen, S. M. Dawsey et al., "Serum 25(OH)vitamin D concentration and risk of esophageal squamous dysplasia," Cancer Epidemiology Biomarkers and Prevention, vol. 16, no. 9, pp. 1889-1893, 2007.

[213] M. L. Melamed, E. D. Michos, W. Post, and B. Astor, "25hydroxyvitamin D levels and the risk of mortality in the general population," Archives of Internal Medicine, vol. 168, no. 15, pp. 1629-1637, 2008.

[214] C. F. Garland, F. C. Garland, E. K. Shaw, G. W. Comstock, K. J. Helsing, and E. D. Gorham, "Serum 25-hydroxyvitamin D and colon cancer: eight-year Prospective Study," Lancet, vol. 2, no. 8673, pp. 1176-1178, 1989.

[215] T. J. Wang, M. J. Pencina, S. L. Booth et al., "Vitamin D deficiency and risk of cardiovascular disease," Circulation, vol. 117, no. 4, pp. 503-511, 2008.

[216] R. Vieth, "Vitamin D supplementation, 25-hydroxyvitamin D concentrations, and safety," American Journal of Clinical Nutrition, vol. 69, no. 5, pp. 842-856, 1999.

[217] R. D. Jackson, A. Z. LaCroix, M. Gass et al., "Calcium plus vitamin D supplementation and the risk of fractures," The New England Journal of Medicine, vol. 354, no. 7, pp. 669-683, 2006.

[218] M. Chung, J. Lee, T. Terasawa, J. Lau, and T. A. Trikalinos, "Vitamin D with or without calcium supplementation for prevention of cancer and fractures: an updated meta-analysis for the U.S. Preventive Services Task Force," Annals of Internal Medicine, vol. 155, pp. 827-838, 2011.

[219] J. Wactawski-Wende, J. Morley Kotchen, G. L. Anderson et al., "Calcium plus vitamin D supplementation and the risk of colorectal cancer," The New England Journal of Medicine, vol. 354, no. 7, pp. 684-696, 2006.

[220] E. L. Ding, S. Mehta, W. W. Fawzi, and E. L. Giovannucci, "Interaction of estrogen therapy with calcium and vitamin D supplementation on colorectal cancer risk: reanalysis of women's health initiative randomized trial," International Journal of Cancer, vol. 122, no. 8, pp. 1690-1694, 2008.

[221] E. A. Jacobson, K. A. James, H. L. Newmark, and K. K. Carroll, "Effects of dietary fat, calcium, and vitamin $\mathrm{D}$ on growth and mammary tumorigenesis induced by 7,12-dimethylbenz(a)anthracene in female Sprague-Dawley rats," Cancer Research, vol. 49 , no. 22, pp. 6300-6303, 1989.
[222] A. Avenell, W. J. Gillespie, L. D. Gillespie, and D. O'Connell, "Vitamin D and vitamin D analogues for preventing fractures associated with involutional and post-menopausal osteoporosis," Cochrane Database of Systematic Reviews, no. 2, Article ID CD000227, 2009.

[223] C. E. Simmons, E. Amir, G. Dranitsaris et al., "Altered calcium metabolism in patients on long-term bisphosphonate therapy for metastatic breast cancer," Anticancer Research, vol. 29, no. 7, pp. 2707-2711, 2009.

[224] E. Amir, C. E. Simmons, O. C. Freedman et al., "A phase 2 trial exploring the effects of high-dose (10,000 IU/day) vitamin D3 in breast cancer patients with bone metastases," Cancer, vol. 116, no. 2, pp. 284-291, 2010.

[225] T. M. Beer, D. Lemmon, B. A. Lowe, and W. D. Henner, "Highdose weekly oral calcitriol in patients with a rising PSA after prostatectomy or radiation for prostate carcinoma," Cancer, vol. 97, no. 5, pp. 1217-1224, 2003.

[226] C. Gross, T. Stamey, S. Hancock, and D. Feldman, "Treatment of early recurrent prostate cancer with 1,25-dihydroxyvitamin D3 (calcitriol)," Journal of Urology, vol. 159, no. 6, pp. 2035-2040, 1998.

[227] T. M. Beer and A. Myrthue, "Calcitriol in cancer treatment: from the lab to the clinic," Molecular Cancer Therapeutics, vol. 3, no. 3, pp. 373-381, 2004.

[228] D. L. Trump, D. M. Potter, J. Muindi, A. Brufsky, and C. S. Johnson, "Phase II trial of high-dose, intermittent calcitriol (1,25 dihydroxyvitamin D3) and dexamethasone in androgenindependent prostate cancer," Cancer, vol. 106, no. 10, pp. 21362142, 2006.

[229] T. Gulliford, J. English, K. W. Colston, P. Menday, S. Moller, and R. C. Coombes, "A phase I study of the vitamin D analogue EB 1089 in patients with advanced breast and colorectal cancer," British Journal of Cancer, vol. 78, no. 1, pp. 6-13, 1998.

[230] C. Mørk Hansen, K. J. Hamberg, E. Binderup, and L. Binderup, "Seocalcitol (EB 1089): a vitamin D analogue of anti-cancer potential. Background, design, synthesis, pre-clinical and clinical evaluation," Current Pharmaceutical Design, vol. 6, no. 7, pp. 803-828, 2000.

[231] T. W. Flaig, A. Barqawi, G. Miller et al., "A phase II trial of dexamethasone, vitamin $\mathrm{D}$, and carboplatin in patients with hormone-refractory prostate cancer," Cancer, vol. 107, no. 2, pp. 266-274, 2006.

[232] T. M. Beer, C. W. Ryan, P. M. Venner et al., "Double-blinded randomized study of high-dose calcitriol plus docetaxel compared with placebo plus docetaxel in androgen-independent prostate cancer: a report from the ASCENT Investigators," Journal of Clinical Oncology, vol. 25, pp. 669-674, 2007.

[233] H. I. Scher, X. Jia, K. Chi et al., "Randomized, open-label phase III trial of docetaxel plus high-dose calcitriol versus docetaxel plus prednisone for patients with castration-resistant prostate cancer," Journal of Clinical Oncology, vol. 29, no. 16, pp. 21912198, 2011.

[234] J. S. Chan, T. M. Beer, D. I. Quinn et al., "A phase II study of highdose calcitriol combined with mitoxantrone and prednisone for androgen-independent prostate cancer," BJU International, vol. 102, no. 11, pp. 1601-1606, 2008.

[235] S. Attia, J. Eickhoff, G. Wilding et al., "Randomized, doubleblinded phase II evaluation of docetaxel with or without doxercalciferol in patients with metastatic, androgen-independent prostate cancer," Clinical Cancer Research, vol. 14, no. 8, pp. 2437-2443, 2008. 
[236] R. Petrioli, A. Pascucci, E. Francini et al., "Weekly high-dose calcitriol and docetaxel in patients with metastatic hormonerefractory prostate cancer previously exposed to docetaxel," $B J U$ International, vol. 100, no. 4, pp. 775-779, 2007.

[237] A. V. Krishnan, D. L. Trump, C. S. Johnson, and D. Feldman, "The role of vitamin D in cancer prevention and treatment," Endocrinology and Metabolism Clinics of North America, vol. 39, no. 2, pp. 401-418, 2010.

[238] K. Kupferschmidt, "Uncertain verdict as vitamin D goes on trial," Science, vol. 337, pp. 1476-1478, 2012.

[239] C. J. Fabian, B. F. Kimler, T. Phillips, and C. M. Zalles, "Levels of 25-hydroxy-vitamin D in pre-menopausal women at high risk for development of breast cancer," Cancer Research, vol. 69, no. 2, supplement 1, 2009. 


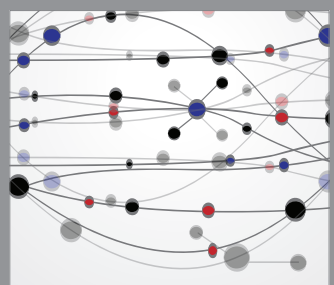

The Scientific World Journal
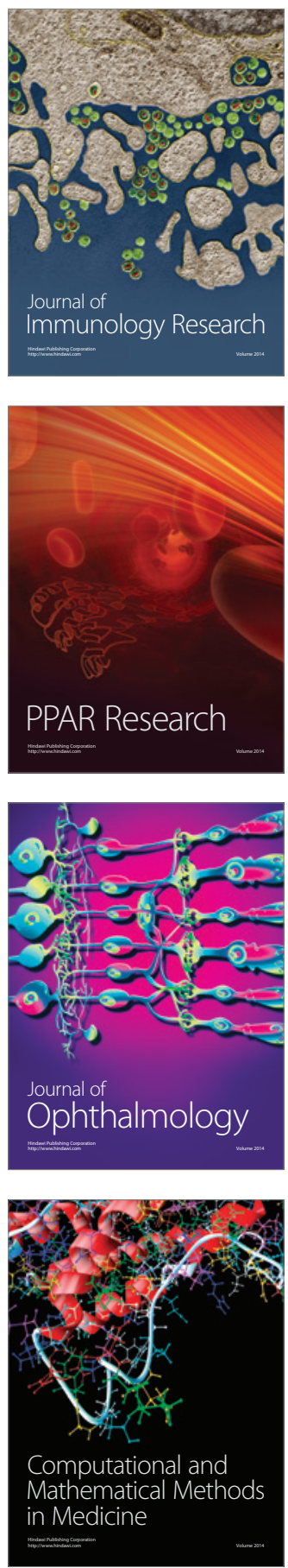

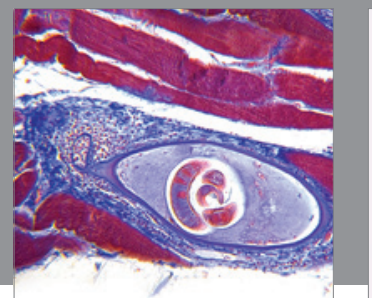

Gastroenterology

Research and Practice
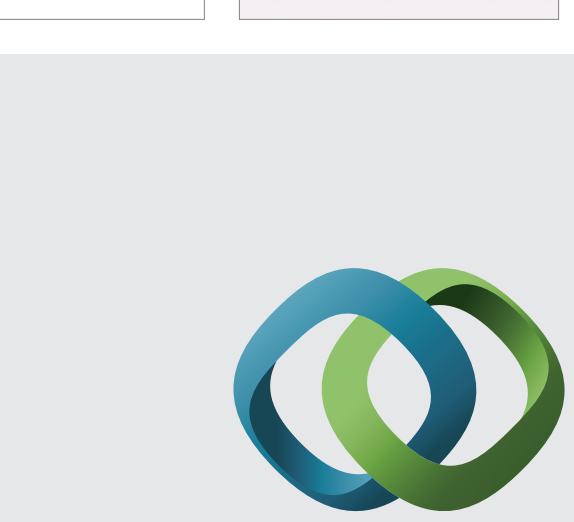

\section{Hindawi}

Submit your manuscripts at

http://www.hindawi.com
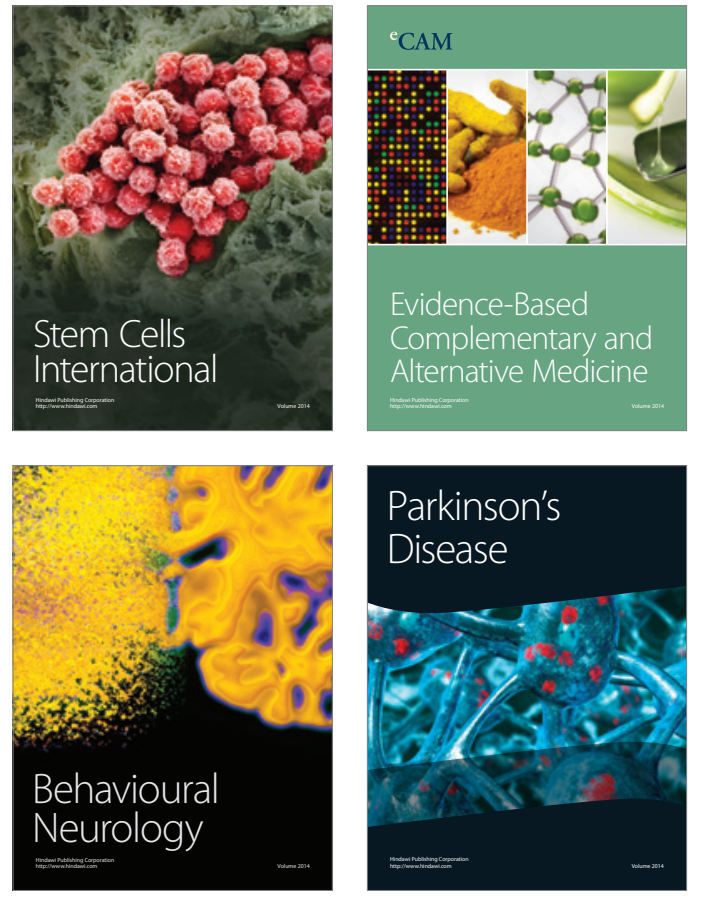
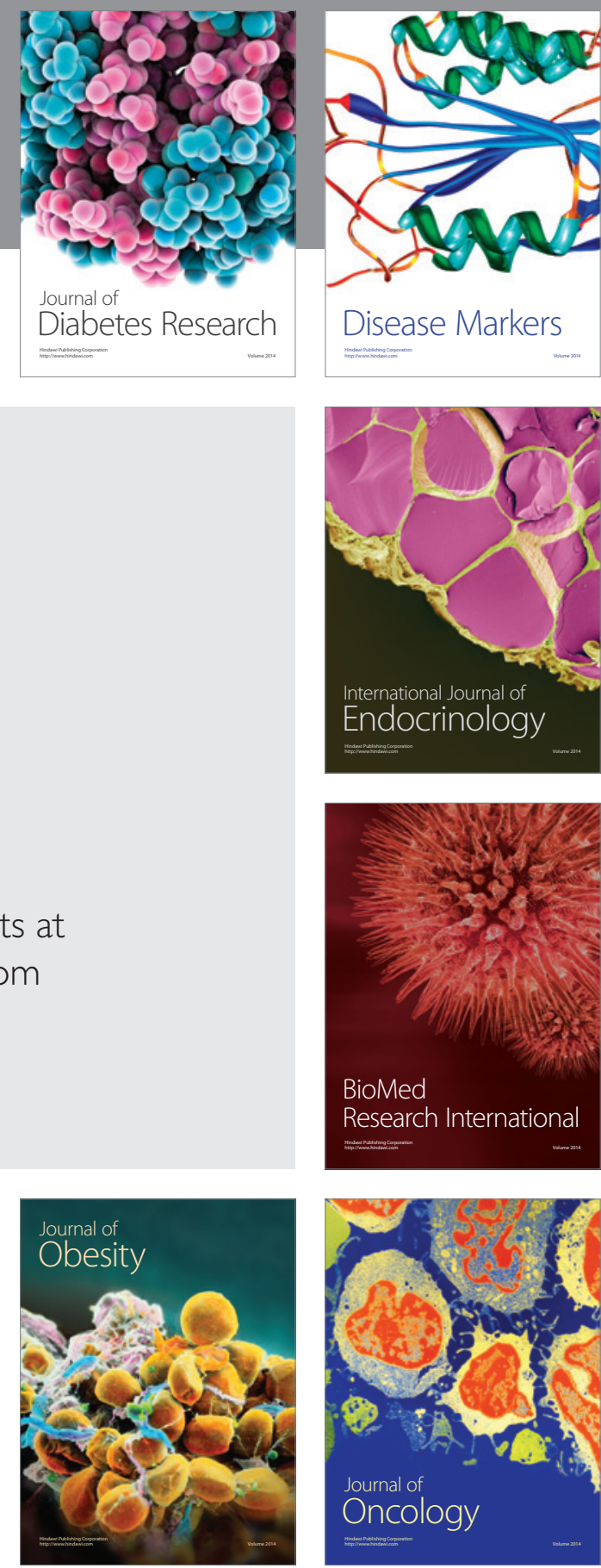

Disease Markers
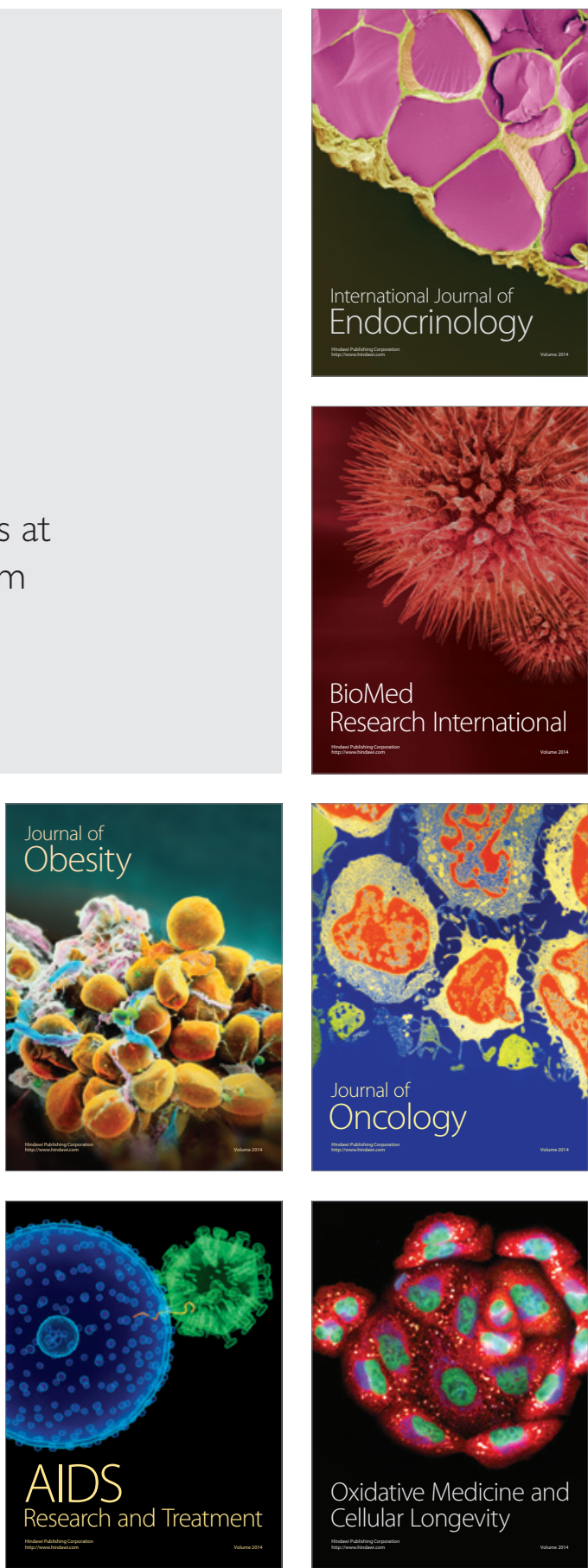